\title{
The effectiveness of gamification to enhance students' mastery on tenses viewed from students' creativity
}

\author{
Benny Krisbiantoro \\ *Correspondence:
Email: bennykrisbiantoro@uhb.ac.id
}

English Education Department, Universitas Harapan Bangsa, Purwokerto, Indonesia

Received:

4 December 2020
Revised:

21 December 2020
Accepted:

31 December 2020
Published:

31 December 2020

\begin{abstract}
The advancement of ICT has resulted in the fast development of games industry by which teachers are creative to design the learning process and to utilize various kinds of gamifications. Gamification is a teaching method that uses game elements with the aim of motivating students to be directly involved in games and learning at the same time so that students get an interesting and enjoyable learning experience. Although many studies have been conducted related to the use gamification, the study on the use of gamification to improve tenses mastery regarded the students' creativity is rarely found. This study was aimed to investigate whether: (1) gamification was more effective than conventional teaching method in enhancing tenses mastery of the second semester students of nursing diploma III; (2) the second semester students with high level of creativity had better tenses mastery than those with low level of creativity; and (3) there was an interaction effect between teaching methods and creativity on enhancing tenses mastery of the second semester students of nursing diploma III of faculty of health of Universitas Harapan Bangsa. The method which was employed in this research was an experimental research. The population of the research was the second semester students of nursing diploma III of faculty of health of Universitas Harapan Bangsa. Two classes were taken by using total sampling technique. The samples in this research were two classes; experimental class consisting of 30 students from $2 A-1$ and control class consisting of 30 students from $2 A-2$. The research instruments consisted of verbal creativity and tenses mastery test. The data were obtained from creativity and tenses mastery test. They were analysed in the terms of their frequency distribution, normality of the sample distribution, and the data homogeneity and then ANOVA test (Multifactor Analysis and Variance) and TUKEY test to test the research hypotheses. The result of the research findings leads to the conclusion that: (1) gamification is more effective than conventional teaching method to enhance tenses mastery of the second semester students; (2) the students having high creativity have better tenses mastery than those having low creativity; and (3) there is an interaction between teaching methods and creativity on enhancing tenses mastery.
\end{abstract}

Keywords: Gamification; Conventional Teaching Method; creativity, tenses mastery; experimental

\section{INTRODUCTION}

Currently, the use of games to motivate people to do something and to direct them to various behaviours has increased very rapidly (Matallaoui et al., 2017). Games are also a very good teaching method because by using games students can be directly involved in the learning process (Dehghanzadeh et al., 2019). One approach that games use recently is gamification. 
Gamification is a game thinking process and game mechanics that involves the user in solving problems. Gamification is the use of design elements that make up a game in a non-game context (Sari \& Hartanto, 2016). Apart from currently being widely applied in various business activities (such as decision making, innovation, teamwork, and marketing), gamification is also predicted to become the next generation application in all matters and problems (Sigala, 2015). Pedagogical approaches such as gamification and conventional games in learning English have magical powers in improving students' English skills in listening, reading, speaking and writing as well as language components such as pronunciation, grammar and vocabulary.

The English language skills of students at Universitas Harapan Bangsa are classified as low. The facts show that learning English at Universitas Harapan Bangsa, especially in the General English 2A and 2B classes in the first semester of the D3 Nursing Study program in the 2019/2020 academic year has several deficiencies, both from teaching methods, learning processes, teaching media to learning evaluation. Based on the results of a preliminary study conducted by researcher, the teaching methods that are often used by some lecturers still tend to use teacher-centred methods. There are very few opportunities for students to practice their English skills both inside and outside the classroom. The learning process is still very minimal in activities that are fun, interactive, explorative, systematic, technology-savvy, and autonomous. The teaching media used are LCDs, laptops, and some handouts which are used as supplementary materials, while the games that are often used are conventional games. In evaluating the learning process, teachers only tend to emphasize a small proportion of speaking and writing skills, both of which are rarely practiced intensively by students during the learning process. In addition, the average score of students' English proficiency in the General English 2A class was 67.99, while the average score of students in the General English 2B class was 68.15.

Considering the facts mentioned above, the researcher wants to know the effectiveness of gamification in learning English, especially tenses. Tenses are the basis of grammar in English. Tenses for most people are often confusing and complicated (Sari et al., 2015). Therefore, the objectives of this study are to investigate whether: 1) gamification method is more effective than conventional teaching method in enhancing the tenses mastery of the second semester students of General English 2 class in the D3 Nursing study program in the 2019/2020 academic year; 2) the students with high creativity have a better mastery on tenses than those with low creativity; and 3) there is an interaction effect between teaching methods and students' creativity.

This research is expected to be able to improve students' mastery of tenses. In addition, this research also helps provide insight into the concepts and applications of gamification in learning English. This research is also believed to be able to contribute to the development of science and technology because in this study researcher uses the internet and computers in the application of gamification. This research is in line with the characteristics of Universitas Harapan Bangsa, namely the use of ICT so that it is expected to be able to assist the development of institutions and the needs and potential of the community as well as all the people around the globe.

\section{Theoretical study Gamification}

The term gamification has appeared in the academic literature since the discussion of Van Benthem as cited in Landers (2014) regarding logic games where he says "in principle, any logical task can be gamified. Van Benthem uses the term to mean the presentation or conversion of a non-game task into a game, which is still a layman's definition today. Gamification is the use of game attributes, as defined by Bedwell's taxonomy, outside the context of a game in order to influence learning-related behaviour and attitudes. Gamification is also defined as a 
learning approach using elements in games or video games with the aim of motivating students in the learning process and maximizing feelings of enjoyment and engagement with the learning process, besides this media can be used to capture things that interest students. and inspire him to continue learning (Lee \& Hammer, 2011 as cited in Lui, 2013). Gamification is the process of using game elements to be adjusted in certain fields which aim to make them more interesting, easy to understand and creative (Pradana, et al., 2018).

Gamification of education is a developing approach for increasing learners' motivation and engagement by incorporating game design elements in educational environments (Dichev \& Dicheva, 2017). Kapp, 2013 as cited in Alsawaier, 2018 defined gamification in pedagogical context as a teaching strategy which is altered to accommodate game elements where, in addition to the learning objectives, the teacher in a gamified classroom will present a challenge or quest that players must work on and lead them to a learning experience. Several other researchers defined gamification as the use of game elements, mechanics, features, design, and structure in a non-game environment or context (Attali \& Arieli, 2015 in Alsawaier, 2018; Dale, 2014; Davis, 2014; Deterding, 2012; Gonzales, et al., 2016; Hanus, 2015; Issacs, 2015; Kapp, 2013; Powers, et al., 2013; Keeler, 2015; Koivisto \& Hamari, 2014; Seaborn \& Fels, 2015; Sheldon, 2011; Whitton \& Moseley, 2010; dan Zichermann \& Cunningham, 2011). According to Werbach \& Hunter, 2012 in Flores, 2015, gamification is use of game elements and game design techniques in a non-game context. It is based on the success of the gaming industry, social media, and decades of research in human psychology. Basically every task, process and theoretical context can be varied.

Based on the description of the gamification definition above, it can be concluded that gamification is a teaching method that uses game elements with the aim of motivating students to be directly involved in games and learning at the same time so that students get an interesting and enjoyable learning experience.

\section{Advantages of gamification}

a. Facilitating student learning experiences in the classroom (Barab et al., 2009 in Lui, 2013).

b. Involving persistence, intelligence, practice, and learning with the aim of achieving success (Gray, 2012 in Lui, 2013).

c. Addressing students' emotional needs and providing opportunities to turn negative emotions into positive experiences (Lee \& Hammer, 2011 in Lui, 2013).

d. Learning becomes more fun, encourages students to complete their learning activities, helps students focus more on and understands the material being studied, and gives students opportunities to compete, explore and excel in class (Jusuf, 2017).

e. Helping the development of cognitive and physical aspects of adults, increasing the level of active role of students in the class, and helping learners understand the material (Deese, 2016 in Setyowati, 2017).

f. Making students more active, directly involved and motivated in learning (Flores, 2015).

g. Increasing user interest in software such as angry bird (for physics lessons), pokemon (for language lessons, art, science, maps) and minecraft (for architecture lessons) (Zichermann \& Cunningham, 2011 in Jusuf, 2017).

h. Allowing students to receive immediate feedback on their progress in the classroom and appreciation for completed assignments (Kapp \& Cone, 2012 in Jusuf, 2017).

\section{Weaknesses of gamification}

a. Games in gamification are predictable and tend to be boring.

b. Games become meaningless if the learning objectives are not well described or are not achieved.

c. Often playing games can be psychological. 
d. Rewards given to students can be used as an external motivation but it is much better if students have internal motivation in learning.

e. The game is the rules. Applying games to learning may even create experiences that are adjusted to the rules so that in the end it still feels like the experience of learning at school in general.

\section{English tenses}

Tenses are changes in verbs that are influenced by the timing and nature of events. All sentences in English cannot be separated from tenses because all sentences must have something to do with the time and nature of their occurrence (Kurniawan, 2010). In English grammar, there are 16 types of tenses, namely:

Table 1. Types of Tenses in English

\begin{tabular}{|c|c|c|c|c|}
\hline Time & Present & Past & Future & Past Future \\
\hline \multirow{4}{*}{$\underset{\substack{0 \\
\stackrel{0}{0}}}{\stackrel{0}{0}}$} & Simple Present & Simple Past & Simple Future & Simple Past Future \\
\hline & Present Continuous & Past Continuous & Future Continuous & Past Future Continuous \\
\hline & Present Perfect & Past Perfect & Future Perfect & Past Future Perfect \\
\hline & $\begin{array}{l}\text { Present } \\
\text { Continuous }\end{array}$ & $\begin{array}{l}\text { Past } \\
\text { Continuous }\end{array}$ & $\begin{array}{l}\text { Future } \\
\text { Continuous }\end{array}$ & $\begin{array}{l}\text { Past Future } \\
\text { Continuous }\end{array}$ \\
\hline
\end{tabular}

The tenses taught in the General English 2 class in the D3 Nursing study program were the simple present tense, simple past tense and simple future tense. The researcher taught the three tenses according to the syllabus in the General English 2 course.

\section{Use of gamification in the teaching of English}

Gamification in the world of education plays a very important role to motivate the students to deeply engage with the teaching and learning process carried out in the classroom since the teachers oftentimes get difficulties to encourage their students to stay tuned in the process of delivering the materials. Gamification offers a new kind of interactive learning by which the teachers provide a more enjoyable and interactive way to the students so that the students do not only gain knowledge but they also experience something new and interesting from gamification.

There are several types of online gamifications that can be implemented in the teaching of English, as follows:

a. Kahoot!

Kahoot! is the granddaddy of the game show review games, launched in August of 2013. In a standard Kahoot! game, questions are displayed to students on a projector or display. Students respond on their own devices.

b. Quizizz

Quizizz takes the excitement of a gameshow-style review game and puts the whole experience in the students' hands. With a traditional Kahoot! game, everyone sees the question and possible answers on the projector and answer simultaneously. Quizizz is different because the questions and possible answers are displayed individually on student devices.

c. Quizlet Live

Quizlet's foray into the game show-style review is the best collaborative game. Instead of students answering individual questions on their individual devices, Quizlet puts students in groups. All possible answers are divided amongst the devices of all students participating. Think of three students with 12 possible answers ... they're divided up with four on each device, so the answer may or may not be on your device. Teams race to get all answers correct in a row to win. 


\section{d. Gimkit}

Gimkit (gimkit.com) is like Quizizz with power-ups. In Quizizz, students collect points cumulatively throughout the game. In Gimkit, students use their points to buy powerups in the store. Power-ups let students earn more points per question, get additional points when they hit a streak, and even lose less points when incorrect.

e. Baambozzle

Baamboozle is a fun game to play with our class as a bell ringer, check in, or review lesson. Play from a single device on a projector, smart board or in an online lesson. No student accounts are needed. It is simple to set up.

f. Factile

Factile lets you create or play jeopardy-style quiz games for our classroom.

g. Quizalize

Quizalize is another quiz-based website. Teachers can create quizzes with multiple- or two-choice question sets or single-word responses

h. Wordwall

With Wordwall we can make custom activities like quizzes, match ups, word games and more for our classroom. Wordwall activities can also be printed out directly or downloaded as a PDF file. The printables can be used along with the interactive or as stand-alone activities.

In this study the researcher utilized quizizz to enhance the students' tenses mastery due to some considerations such as its easiness, simplicity, usability, accessibility and userfriendliness. The procedures of implementing quizizz to improve the students' tenses mastery in the experimental class can be seen in table 2.

Table 2. Procedures of Implementing Quizziz

\begin{tabular}{|c|c|c|c|c|}
\hline $\begin{array}{l}\text { Meeting/ } \\
\text { Materials }\end{array}$ & $\begin{array}{c}\text { Learning } \\
\text { Objectives }\end{array}$ & Teacher's Activities & Students' Activities & $\begin{array}{c}\text { Duration/ } \\
\text { Media }\end{array}$ \\
\hline $\begin{array}{l}\text { Meeting } \\
\text { 1/Simple } \\
\text { Present } \\
\text { Tense } \\
\text { (Nominal } \\
\text { Sentence) }\end{array}$ & $\begin{array}{l}\text { Creating an } \\
\text { account, } \\
\text { materials and } \\
\text { review quiz. }\end{array}$ & $\begin{array}{l}\text { - Creating an account in } \\
\text { www.quizizz.com } \\
\text { using our email. } \\
\text { - Choosing a role to be a } \\
\text { teacher and complete } \\
\text { the data. } \\
\text { - Creating materials and } \\
\text { review quiz and setting } \\
\text { up the answer choices } \\
\text { and question preview } \\
\text { and then clicking finish } \\
\text { and creating the } \\
\text { materials and review } \\
\text { quiz. } \\
\text { - Sharing the code to the } \\
\text { students to access the } \\
\text { quizizz. } \\
\text { - Asking the students to } \\
\text { enter the code. }\end{array}$ & $\begin{array}{l}\text { - While waiting for the } \\
\text { teacher's instruction, do the } \\
\text { online creativity test for } \\
\text { about } 40 \text { minutes through } \\
\text { google form. } \\
\text { - Entering the code and } \\
\text { listening to the teacher's } \\
\text { presentation about simple } \\
\text { present tense. } \\
\text { - Starting the game quiz to } \\
\text { review their mastery on } \\
\text { simple present tense. } \\
\text { - Knowing the leader board of } \\
\text { the first meeting game. }\end{array}$ & $\begin{array}{l}90 \text { minutes/ } \\
\text { Zoom/Google } \\
\text { Form }\end{array}$ \\
\hline $\begin{array}{l}\text { Meeting } \\
\text { 2/Review } \\
\text { and new } \\
\text { material } \\
\text { about simple } \\
\text { present tense } \\
\text { (verbal } \\
\text { sentence) }\end{array}$ & $\begin{array}{l}\text { Reviewing the } \\
\text { previous } \\
\text { material about } \\
\text { simple present } \\
\text { tense (nominal } \\
\text { sentence) }\end{array}$ & $\begin{array}{l}\text { - Having the students to } \\
\text { enter the new code in } \\
\text { quizizz website to do a } \\
\text { review quiz of meeting } \\
1 \text {. } \\
\text { - Eliciting the students' } \\
\text { prior knowledge about }\end{array}$ & $\begin{array}{l}\text { - Doing the review quiz of the } \\
\text { previous material. } \\
\text { - Telling the teacher about } \\
\text { what they have known and } \\
\text { what they have not known as } \\
\text { well as what they want to } \\
\text { know about the material in }\end{array}$ & $\begin{array}{l}90 \text { minutes/ } \\
\text { Zoom }\end{array}$ \\
\hline
\end{tabular}




\begin{tabular}{|c|c|c|c|c|}
\hline & & $\begin{array}{l}\text { simple present tense } \\
\text { (verbal sentence). } \\
\text { - Presenting the material } \\
\text { using quizizz. } \\
\text { - Asking the students to } \\
\text { do the second meeting } \\
\text { game to check their } \\
\text { mastery on simple } \\
\text { present tense (verbal } \\
\text { sentence) }\end{array}$ & $\begin{array}{l}\text { this meeting. } \\
\text { - Paying attention on the } \\
\text { teacher's presentation. } \\
\text { - Doing a game quiz of verbal } \\
\text { sentence in simple present } \\
\text { tense. }\end{array}$ & \\
\hline $\begin{array}{l}\text { Meeting } \\
\text { 3/Simple } \\
\text { Past Tense } \\
\text { (Nominal } \\
\text { Sentence) }\end{array}$ & $\begin{array}{l}\text { - Reviewing } \\
\text { the previous } \\
\text { material } \\
\text { about simple } \\
\text { present tense } \\
\text { - Explaining } \\
\text { material } \\
\text { about } \\
\text { nominal } \\
\text { sentence in } \\
\text { simple past } \\
\text { tense }\end{array}$ & $\begin{array}{l}\text { - Having the students to } \\
\text { enter the new code in } \\
\text { quizizz website to do a } \\
\text { review quiz of meeting } \\
2 \text {. } \\
\text { - Eliciting the students' } \\
\text { prior knowledge about } \\
\text { simple past tense } \\
\text { (nominal sentence). } \\
\text { - Presenting the material } \\
\text { using quizizz. } \\
\text { - Asking the students to } \\
\text { do the third meeting } \\
\text { game to check their } \\
\text { mastery on simple past } \\
\text { tense (nominal } \\
\text { sentence) }\end{array}$ & $\begin{array}{l}\text { - Doing the review quiz of the } \\
\text { previous material. } \\
\text { - Telling the teacher about } \\
\text { what they have known and } \\
\text { what they have not known as } \\
\text { well as what they want to } \\
\text { know about the material in } \\
\text { this meeting. } \\
\text { - Paying attention on the } \\
\text { teacher's presentation. } \\
\text { - Doing a game quiz of } \\
\text { nominal sentence in simple } \\
\text { past tense. }\end{array}$ & $\begin{array}{l}90 \text { minutes/ } \\
\text { Zoom }\end{array}$ \\
\hline $\begin{array}{l}\text { Meeting } \\
\text { 4/Simple } \\
\text { Past Tense } \\
\text { (Verbal } \\
\text { Sentence) }\end{array}$ & $\begin{array}{l}\text { - Reviewing } \\
\text { the previous } \\
\text { material } \\
\text { about simple } \\
\text { past tense } \\
\text { (nominal } \\
\text { sentence) } \\
\text { - Explaining } \\
\text { material } \\
\text { about verbal } \\
\text { sentence in } \\
\text { simple past } \\
\text { tense }\end{array}$ & $\begin{array}{l}\text { - Having the students to } \\
\text { enter the new code in } \\
\text { quizizz website to do a } \\
\text { review quiz of meeting } \\
\text { 3. } \\
\text { - Eliciting the students' } \\
\text { prior knowledge about } \\
\text { simple past tense } \\
\text { (verbal sentence). } \\
\text { - Presenting the material } \\
\text { using quizizz. } \\
\text { - Asking the students to } \\
\text { do the fourth meeting } \\
\text { game to check their } \\
\text { mastery on simple past } \\
\text { tense (verbal sentence) }\end{array}$ & $\begin{array}{l}\text { - Doing the review quiz of the } \\
\text { previous material. } \\
\text { - Telling the teacher about } \\
\text { what they have known and } \\
\text { what they have not known as } \\
\text { well as what they want to } \\
\text { know about the material in } \\
\text { this meeting. } \\
\text { - Paying attention on the } \\
\text { teacher's presentation. } \\
\text { - Doing a game quiz of verbal } \\
\text { sentence in simple past tense. }\end{array}$ & $\begin{array}{l}90 \text { minutes/ } \\
\text { Zoom }\end{array}$ \\
\hline $\begin{array}{l}\text { Meeting } \\
\text { 5/Simple } \\
\text { Future Tense } \\
\text { (WILL) }\end{array}$ & $\begin{array}{l}\text { - Reviewing } \\
\text { the previous } \\
\text { material } \\
\text { about simple } \\
\text { past tense } \\
\text { (verbal } \\
\text { sentence) } \\
\text { - Explaining } \\
\text { material } \\
\text { about WILL } \\
\text { in simple } \\
\text { future tense }\end{array}$ & $\begin{array}{l}\text { - Having the students to } \\
\text { enter the new code in } \\
\text { quizizz website to do a } \\
\text { review quiz of meeting } \\
4 \text {. } \\
\text { - Eliciting the students' } \\
\text { prior knowledge about } \\
\text { simple future tense } \\
\text { (WILL). } \\
\text { - Presenting the material } \\
\text { using quizizz. } \\
\text { - Asking the students to } \\
\text { do the fifth meeting } \\
\text { game to check their } \\
\text { mastery on simple } \\
\text { future tense (WILL) }\end{array}$ & $\begin{array}{l}\text { - Doing the review quiz of the } \\
\text { previous material. } \\
\text { - Telling the teacher about } \\
\text { what they have known and } \\
\text { what they have not known as } \\
\text { well as what they want to } \\
\text { know about the material in } \\
\text { this meeting. } \\
\text { - Paying attention on the } \\
\text { teacher's presentation. } \\
\text { - Doing a game quiz of WILL } \\
\text { in simple future tense. }\end{array}$ & $\begin{array}{l}90 \text { minutes/ } \\
\text { Zoom }\end{array}$ \\
\hline
\end{tabular}




\begin{tabular}{|c|c|c|c|c|}
\hline $\begin{array}{l}\text { 6/Simple } \\
\text { Future Tense } \\
\text { (BE GOING } \\
\text { TO) }\end{array}$ & $\begin{array}{l}\text { the previous } \\
\text { material } \\
\text { about simple } \\
\text { future tense } \\
\text { (WILL) } \\
\text { - Explaining } \\
\text { material } \\
\text { about BE } \\
\text { GOING TO } \\
\text { in simple } \\
\text { future tense }\end{array}$ & $\begin{array}{l}\text { enter the new code in } \\
\text { quizizz website to do a } \\
\text { review quiz of meeting } \\
5 \text {. } \\
\text { - Eliciting the students' } \\
\text { prior knowledge about } \\
\text { simple future tense (BE } \\
\text { GOING TO). } \\
\text { - Presenting the material } \\
\text { using quizizz. } \\
\text { - Asking the students to } \\
\text { do the sixth meeting } \\
\text { game to check their } \\
\text { mastery on simple } \\
\text { future tense (BE } \\
\text { GOING TO) }\end{array}$ & $\begin{array}{l}\text { previous material. } \\
\text { - Telling the teacher about } \\
\text { what they have known and } \\
\text { what they have not known as } \\
\text { well as what they want to } \\
\text { know about the material in } \\
\text { this meeting. } \\
\text { - Paying attention on the } \\
\text { teacher's presentation. } \\
\text { - Doing a game quiz of BE } \\
\text { GOING TO in simple future } \\
\text { tense. }\end{array}$ & Zoom \\
\hline $\begin{array}{l}\text { Meeting } \\
\text { 7/Review all } \\
\text { leaned } \\
\text { materials }\end{array}$ & $\begin{array}{l}\text { - Reviewing } \\
\text { the previous } \\
\text { materials } \\
\text { about simple } \\
\text { present } \\
\text { tense, simple } \\
\text { past tense, } \\
\text { and simple } \\
\text { future tense }\end{array}$ & $\begin{array}{l}\text { - Having the students to } \\
\text { enter the new code in } \\
\text { quizizz website to do a } \\
\text { review quiz of all learnt } \\
\text { tenses. }\end{array}$ & $\begin{array}{l}\text { - Doing the review quiz of the } \\
\text { previous materials. }\end{array}$ & $\begin{array}{l}90 \text { minutes/ } \\
\text { Zoom }\end{array}$ \\
\hline $\begin{array}{l}\text { Meeting } \\
\text { 8/Post-Test }\end{array}$ & $\begin{array}{lr}\text { Giving a } \\
\text { post-test on } \\
\text { tenses } \\
\text { mastery }\end{array}$ & $\begin{array}{l}\text { Asking the students to } \\
\text { do the post-test through } \\
\text { google form. }\end{array}$ & Doing the post-test & $\begin{array}{l}90 \\
\text { minutes/google } \\
\text { form }\end{array}$ \\
\hline
\end{tabular}

On the other way around, the researcher applied conventional teaching method (lecturing) to enhance the students' tenses mastery in the control class. The number of the meeting as well as its sequence is 8 meetings or the same as applied in the experimental class. The media used during this online conventional teaching method are WhatsApp Group and Zoom. The control class is also given the creativity test in the first meeting and a post-test in the last meeting.

\section{Creativity}

Creativity is the modification of something that already exists into a new concept. In other words, there are two old concepts which are combined into a new concept (Semiawan, 2009: 44). Creativity is a person's ability to create something new, the process of constructing ideas that can be applied to solve problems and meaningful activities. Creativity involves mental and social processes to generate newly developed ideas to be conveyed and shared. A person's creativity is about the ability to process new ideas in his mind which is supported by the basic function of intelligence. A person's creativity can be seen in his desire to take part in an activity enthusiastically, to generate new and fresh ideas, to behave assertively, and to share with others. In Gamification, players must use their imagination and creativity in order to complete the game successfully. Without creativity, a player will not be able to win the game. Even the game in gamification requires players to be able to pass several stages and must be able to solve several clues so that they can win the game. Prambayun et al., (2016) stated that players are required to be creative in using the gamification system, there are many ways to get more points, there are special cards that can be used to help play, there are discussion forums that have no comment limit, there are bonus quests that have great rewards. Therefore, in this study, the researcher wanted to find out how creative students were in playing using gamification media which was associated with learning English tenses. 


\section{Study of relevant researches}

There are several studies that are relevant to research to be carried out by researchers, including research conducted by Yanes \& Bououd (2019) who examined the use of gamification and serious games for learning English and the results of his research were that there were several things that needed to be considered before adopting gamification, for example, is SWOT; then research conducted by Dehghanzadeh, et al., (2019) who examined the use of gamification to support learning English as a second language and the results were how to design digital gamification and student learning experiences; research of Al-hadithy \& Ali (2018) about gamification in learning English for academic purposes and the result was an increase in active learning, student involvement, self-efficacy, independent learning and an increase in student summative assessment after the application of gamification in the form of Kahoot.

García \& Alvaro (2017) examined gamification in teaching English in Basic Education and the result was that gamification was an innovative method that could be useful in language teaching because it involved a variety of things such as effort, involvement, and motivation and all the elements that played an important role in the acquisition of different linguistic skills. Flores (2015) investigated the use of gamification to improve second language learning and the result was that the use of gamification in second language learning contributed positively to the student learning experience. Xiang, et al., (2014) examined the effectiveness of gamification in vocational engineering education and the result was an increase in learning and students gained better knowledge in vocational engineering topics.

Lui (2013) conducted a case study research on the use of gamification in vocabulary learning and the result was that students preferred to use technology to learn vocabulary and gamification was proven to improve student attitudes towards language learning; Sari, et al., (2015) investigated the application of the concept of gamification to web-based learning of English tenses and the result was that learning web-based English tenses could improve students' ability to master tenses.

As mentioned above, some of these academic studies claim the positive effects of gamification on learning both English and other subjects. However, these previous studies did not mention the link between gamification and creativity. To complement these gaps, the researcher wanted to test the implementation of gamification and measure the effectiveness of gamification in learning tenses.

\section{Hypotheses}

This study formulated the following hypotheses:

1. Gamification Teaching Method is more effective than conventional teaching methods to improve the students' mastery on English tenses in the General English 2 semester 2 class of D3 Nursing Study Program, Faculty of Health, Universitas Harapan Bangsa Purwokerto;

2. Students with high creativity have better tenses mastery than students with low creativity;

3. There is an interaction effect between teaching methods and creativity on improving students' tenses mastery.

\section{METHOD \\ Respondents}

The research subjects were students of General English 2 class in the second semester of the D3 Nursing Study program. The study population consisted of 60 students divided into two classes, namely General English 2 level A class (30 students) and General English 2 level B class (30 students). The research samples were General English 2A-1 as the experimental group and General English 2A-2 as the control group. The experimental group was given treatment in the 
form of the gamification teaching method, while the control group did not receive any treatment.

\section{Instruments}

The instruments used in this study were a test of tenses mastery and a test of creativity. Tenses mastery test that was used in this research was a multiple choice test. It was used to measure the students' mastery on tenses especially simple present tense, simple past tense and simple future tense. Meanwhile, the researcher occupied verbal creativity test to measure one's ability to form and create new ideas and then combine them into something new referring to the existing information. The researchers used the median of the creativity test scores to determine the level of creativity for each control and experimental group. The aspects of the verbal creativity test were fluency, flexibility, originality, elaboration and redefinition.

\section{Procedures}

The method employed in this research was an experimental method with a factorial design. In this study, the researcher utilized total sampling to determine the samples. There was one dependent variable and two independent variables in this research. The dependent variable was tenses mastery and the independent variables were teaching methods and creativity.

\section{Data analysis}

Techniques of analyzing the data utilized in this study were (1) descriptive statistics; (2) normality and homogeneity; (3) ANOVA; (4) TUKEY; and (5) Statistical Hypothesis.

\section{RESULTS AND DISCUSSION \\ Data Description}

The data description in this study is divided into several parts which are described as follows:

\section{The Description of the Students' Tenses Mastery Scores Taught Using Gamification}

The students' tenses mastery scores which are taught using gamification are presented in the table 3.

Table 3. The Students' Tenses Mastery Scores Which Are Taught Using Gamification

\begin{tabular}{ccccccc}
\hline $\mathbf{N}$ & Mean & Mode & Median & Standard Deviation & Highest & Lowest \\
\hline 30 & 82.16 & 93.73 & 89 & 14.90 & 98 & 50 \\
\hline
\end{tabular}

From table 3, the students' tenses mastery mean score was 82.16 , median 89 , mode 93.73 and standard deviation 14.90. Then, the frequency distribution, polygons and histograms of the tenses mastery scores of students taught using gamification are depicted in table 4 and figure 1.

Table 4. Frequency Distribution of Students' Tenses Mastery Scores Taught Using Gamification

\begin{tabular}{cccccc}
\hline Group Limit & Median $\left(\mathbf{X}_{\mathbf{i}}\right)$ & $\mathbf{f}_{\mathbf{i}}$ & $\mathbf{X}_{\mathbf{i}} \mathbf{i}$ & $\mathbf{X}_{\mathbf{i}}{ }^{\mathbf{2}}$ & $\mathbf{f}_{\mathbf{i}} \mathbf{X}_{\mathbf{i}}{ }^{2}$ \\
\hline $48.5-56.5$ & 52.5 & 6 & 315 & 99225 & 595350 \\
\hline $57.5-65.5$ & 61.5 & 0 & 0 & 0 & 0 \\
\hline $66.5-74.5$ & 70.5 & 1 & 70.5 & 4970.25 & 4970.25 \\
\hline $75.5-83.5$ & 79.5 & 4 & 318 & 101124 & 404496 \\
\hline $84.5-92.5$ & 88.5 & 9 & 796.5 & 634412 & 5709710.25 \\
\hline $93.5-100.5$ & 96.5 & 10 & 965 & 931225 & 9312250 \\
\hline Total & & & 2465 & 1770957 & 16026776.5 \\
\hline
\end{tabular}




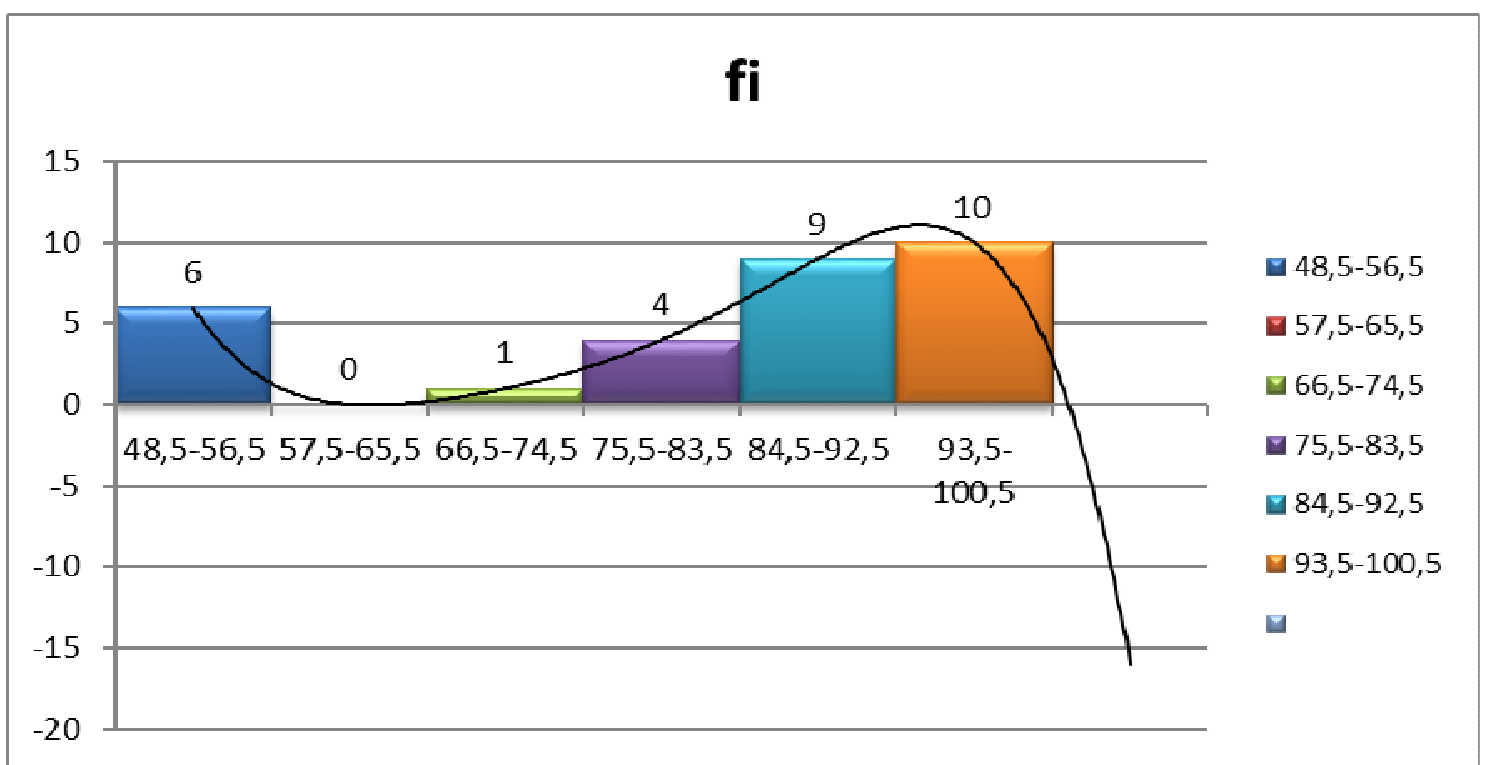

Figure 1. Histogram and Polygon of the Students' Tenses Mastery Scores Taught Using Gamification

\section{The Description of the Students' Tenses Mastery Scores Taught Using Conventional} Teaching Method

The students' tenses mastery scores which are taught using conventional teaching method are presented intable 5.

Table 5. The Students' Tenses Mastery Scores Which Are Taught Using Conventional Teaching Method

\begin{tabular}{lcccccc} 
N & Mean & Mode & Median & Standard Deviation & Highest & Lowest \\
\hline 30 & 66.96 & 87.30 & 80.08 & 22.29 & 90 & 20 \\
\hline
\end{tabular}

From table 5, the students' tenses mastery mean score was 66.96 , median 80.08 , mode 87.30 and standard deviation 22.29. Then, the frequency distribution, polygons and histograms of the tenses mastery scores of students taught using conventional teaching method are depicted in table 6 and figure 2.

Table 6. Frequency Distribution of Students' Tenses Mastery Scores Taught Using Conventional Teaching Method

\begin{tabular}{llllll}
\hline Group Limit & Median $\left(\mathbf{X}_{\mathbf{i}}\right)$ & $\mathbf{f}_{\mathbf{i}}$ & $\mathbf{X}_{\mathbf{i}} \mathbf{f}_{\mathbf{i}}$ & $\mathbf{X}_{\mathbf{i}}{ }^{2}$ & 18496 \\
\hline $28.5-39.5$ & 34 & 4 & 136 & 2116 & $\mathbf{f}_{\mathbf{i}} \mathbf{X}_{\mathbf{i}}{ }^{2}$ \\
\hline $40.5-51.5$ & 46 & 1 & 46 & 30276 & 2116 \\
\hline $52.5-63.5$ & 58 & 3 & 174 & 176400 & 90828 \\
\hline $64.5-75.5$ & 70 & 6 & 420 & 60516 & 1058400 \\
\hline $76.5-87.5$ & 82 & 3 & 246 & 1493284 & 181548 \\
\hline $88.5-99.5$ & 94 & 13 & 1222 & & 19412692 \\
\hline
\end{tabular}




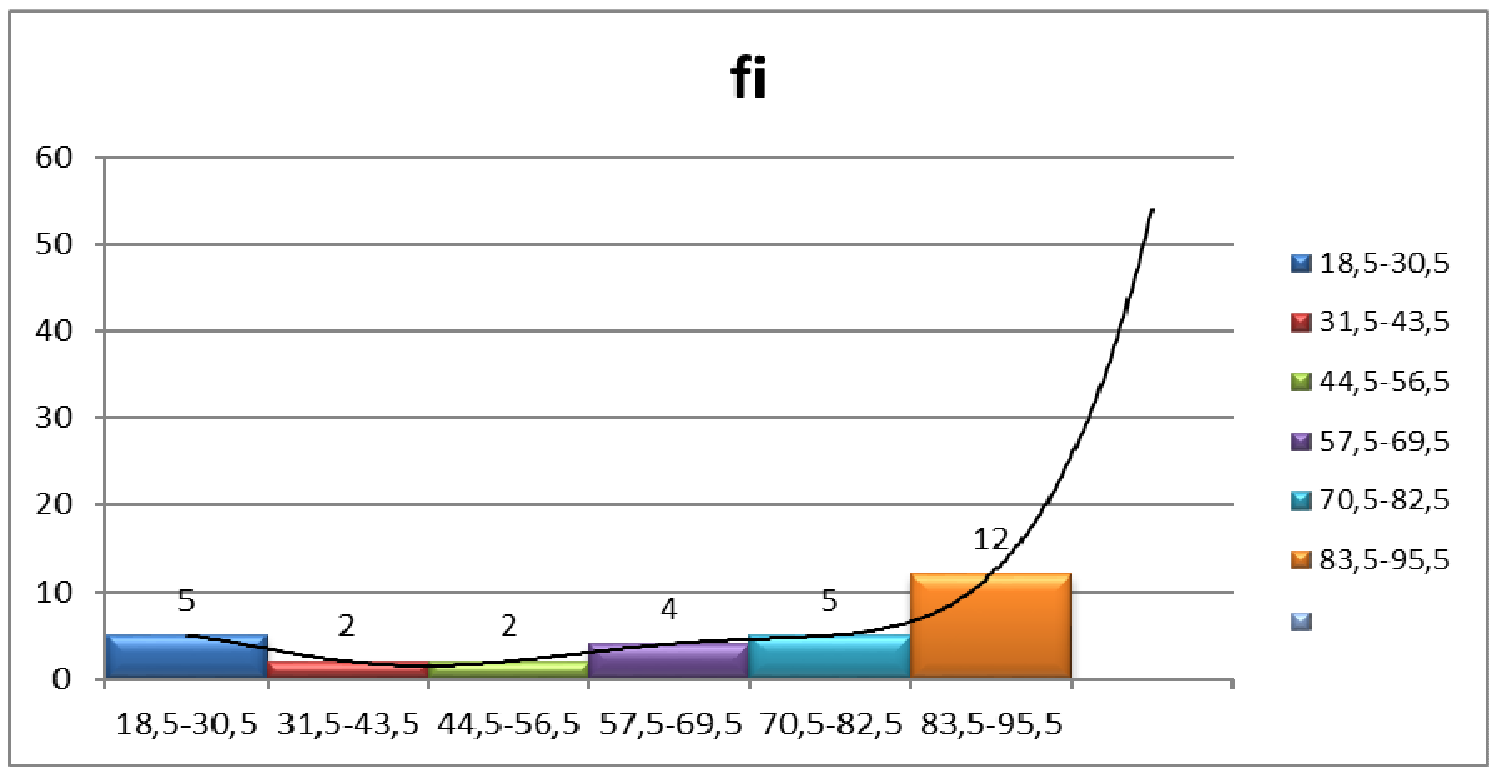

Figure 2. Histogram and Polygon of the Students' Tenses Mastery Scores Taught Using Conventional Teaching Method

3. The Description of Tenses Mastery Scores of the Students Having High Creativity Level The tenses mastery scores of the students who have high creativity are figured out in table 7.

Table 7. The Tenses Mastery Scores of the Students Having High Creativity Level

\begin{tabular}{lllllll}
\hline N & Mean & Mode & Median & Standard Deviation & Highest & Lowest \\
\hline 30 & 74.8 & 93 & 86.23 & 20.61 & 97 & 28 \\
\hline
\end{tabular}

As described in the table 7, it is seen that the mean score of tenses mastery of the students who have high creativity is 74.8 , the median is 86.23 , the mode is 93 , and the standard deviation is 20.61. The frequency distribution, the polygon, and the histogram of the students' tenses mastery are described in table 8 and figure 3.

Table 8. The Frequency Distribution of the Tenses Mastery Scores of the Students Who Have High Creativity Level

\begin{tabular}{llllll}
\hline Group Limit & Median $\left(\mathbf{X}_{\mathbf{i}}\right)$ & $\mathbf{f}_{\mathbf{i}}$ & $\mathbf{X}_{\mathbf{i}} \mathbf{f}_{\mathbf{i}}$ & $\mathbf{X}_{\mathbf{i}}{ }^{2}$ & $\mathbf{f}_{\mathbf{i}} \mathbf{X}_{\mathbf{i}}{ }^{\mathbf{2}}$ \\
\hline $28.5-39.5$ & 34 & 4 & 136 & 18496 & 73984 \\
\hline $40.5-51.5$ & 46 & 1 & 46 & 2116 & 2116 \\
\hline $52.5-63.5$ & 58 & 3 & 174 & 30276 & 90828 \\
\hline $64.5-75.5$ & 70 & 6 & 420 & 176400 & 1058400 \\
\hline $76.5-87.5$ & 82 & 3 & 246 & 60516 & 181548 \\
\hline $88.5-99.5$ & 94 & 13 & 1222 & 1493284 & 19412692 \\
\hline Total & & 30 & 2244 & 1781088 & 20819568 \\
\hline
\end{tabular}




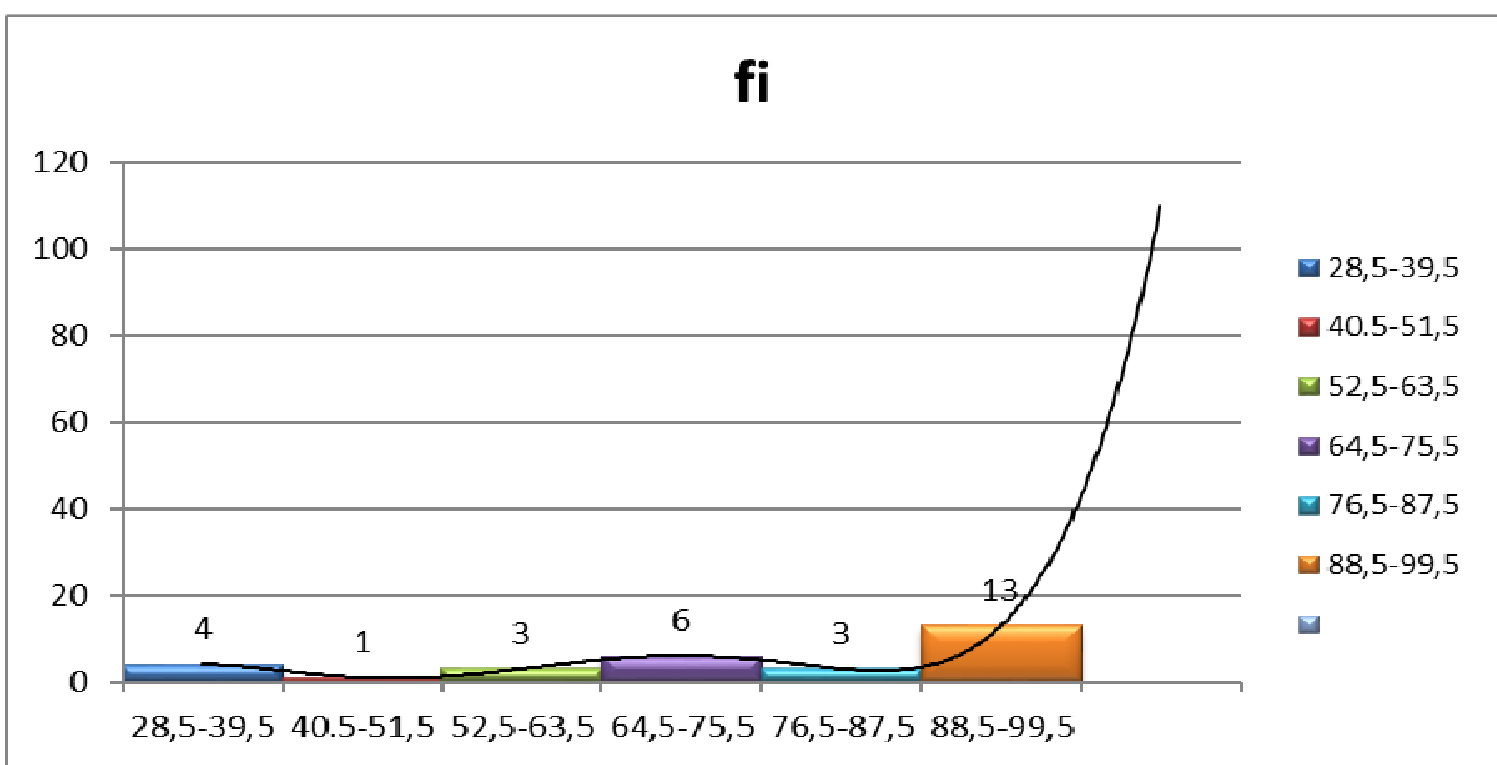

Figure 3. The Histogram and Polygon of the Tenses Mastery Scores of the Students Who Have High Creativity Level

4. The Description of the Tenses Mastery Scores of the Students Having Low Creativity Level The tenses mastery scores of the students who have low creativity are seen in table 9.

Table 9. The Tenses Mastery Scores of the Students Having Low Creativity Level

\begin{tabular}{lllllll} 
N & Mean & Mode & Median & Standard Deviation & Highest & Lowest \\
\hline 30 & 65.46 & 79.81 & 75 & 21.23 & 87 & 10
\end{tabular}

As presented in the table 9 , it is described that the mean score of tenses mastery of the students who have low creativity is 65.46 , the median is 75 , the mode is 79.81 , and the standard deviation is 21.23 . The frequency distribution, the polygon, and the histogram of the students' tenses mastery are seen in table 10 and figure 4.

Table 10. The Frequency Distribution of the Tenses Mastery Scores of the Students Who Have Low Creativity Level

\begin{tabular}{llllll}
\hline Group Limit & Median $\left(\mathbf{X}_{\mathbf{i}}\right)$ & $\mathbf{f}_{\mathbf{i}}$ & $\mathbf{X}_{\mathbf{i}} \mathbf{f}$ & $\mathbf{X}_{\mathbf{i}}{ }^{2}$ & $\mathbf{f}_{\mathbf{i}} \mathbf{X}^{\mathbf{2}}$ \\
\hline $10.5-22.5$ & 16.5 & 3 & 49,5 & 2450.25 & 7350.75 \\
\hline $23.5-35.5$ & 29.5 & 0 & 0 & 0 & 0 \\
\hline $36.5-48.5$ & 42.5 & 4 & 170 & 28900 & 115600 \\
\hline $49.5-61.5$ & 55.5 & 2 & 111 & 12321 & 24642 \\
\hline $62.5-74.5$ & 68.5 & 6 & 411 & 168921 & 1013526 \\
\hline $75.5-87.5$ & 81.5 & 15 & 1222,5 & 1494506.25 & 22417593.75 \\
& & & & & 1707098.5 \\
\hline Total & & 30 & 1964 & & 23578712.5 \\
\hline
\end{tabular}




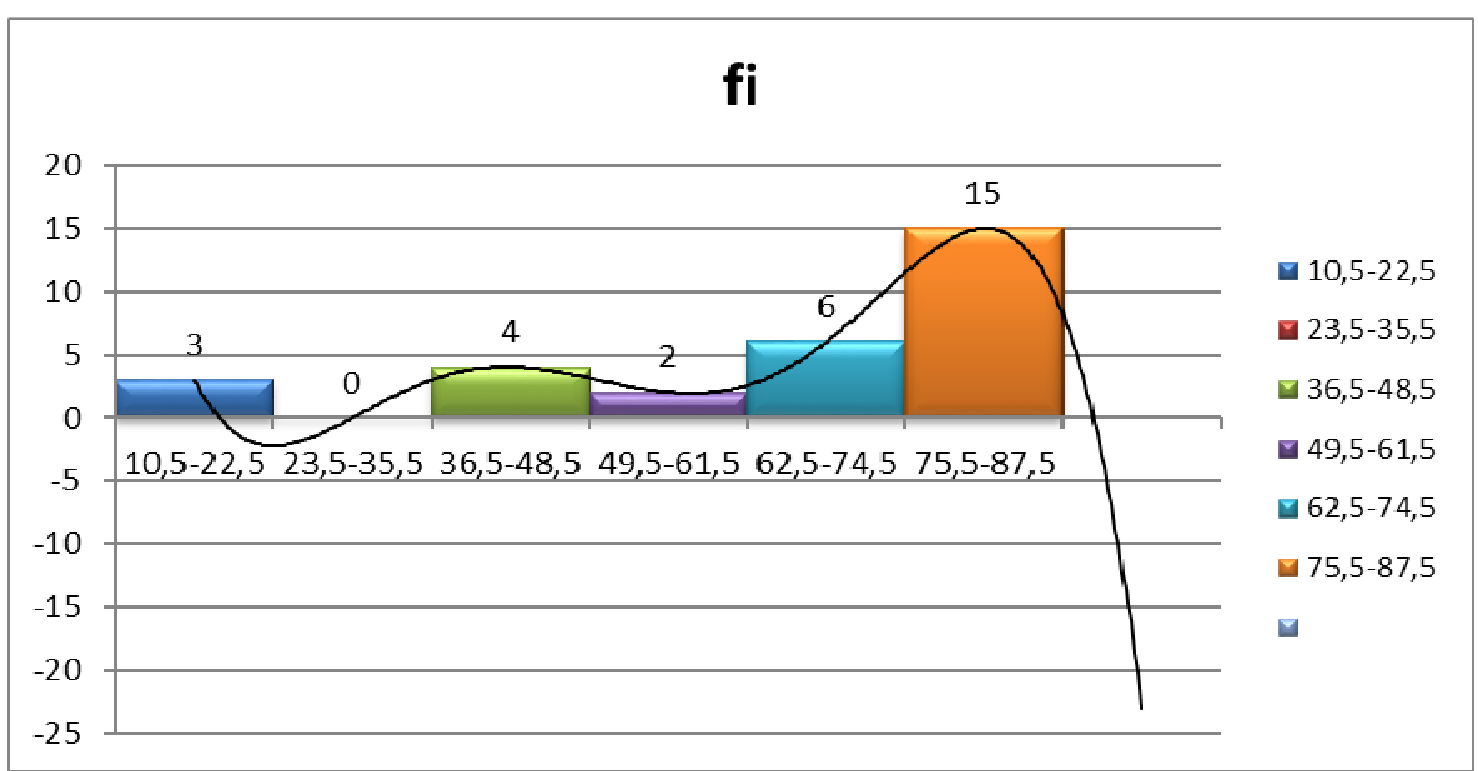

Figure 4. The Histogram and Polygon of the Tenses Mastery Scores of the Students Who Have Low Creativity Level

5. The Description of the Tenses Mastery Scores of the Students Having High Creativity Level and Taught by Using Gamification

The tenses mastery scores of the students having high creativity and taught by using Gamification are presented in table 11.

Table 11. The Tenses Mastery Scores of the Students Having High Creativity Level and Taught by Using Gamification

\begin{tabular}{lllllll}
\hline N & Mean & Mode & Median & Standard Deviation & Highest & Lowest \\
\hline 15 & 76.1 & 94.29 & 80.63 & 15.67 & 97 & 50 \\
\hline
\end{tabular}

As figured out in the table 11, it is revealed that the mean score of tenses mastery of the students having high creativity and taught by using gamification is 76.1 , the median is 80.63 , the mode is 94.29 , and the standard deviation is 15.67 . The frequency distribution, the polygon, and the histogram of the students' tenses mastery are described in table 12 and figure 5.

Table 12. The Frequency Distribution of the Tenses Mastery Scores of the Students Having High Creativity and Taught by Using Gamification

\begin{tabular}{lccccc}
\hline $\begin{array}{l}\text { Group } \\
\text { Limit }\end{array}$ & Median $\left(\mathbf{X}_{\mathbf{i}}\right)$ & $\mathbf{f}_{\mathbf{i}}$ & $\mathbf{X}_{\mathbf{i}} \mathbf{f}_{\mathbf{i}}$ & $\mathbf{X}_{\mathbf{i}}{ }^{\mathbf{2}}$ & $\mathbf{f}_{\mathbf{i}} \mathbf{X}_{\mathbf{i}}{ }^{\mathbf{2}}$ \\
\hline $50.5-59.5$ & 55 & 3 & 165 & 27225 & 81675 \\
\hline $60.5-69.5$ & 62.5 & 1 & 62.5 & 3906,25 & 3906,25 \\
\hline $70.5-79.5$ & 70 & 1 & 70 & 4900 & 4900 \\
\hline $80.5-89.5$ & 78 & 2 & 156 & 24336 & 48672 \\
\hline $90.5-99.5$ & 86 & 8 & 688 & 473344 & 3786752 \\
\hline Total & & 15 & 1141.5 & 533711.25 & 3925905.25 \\
\end{tabular}




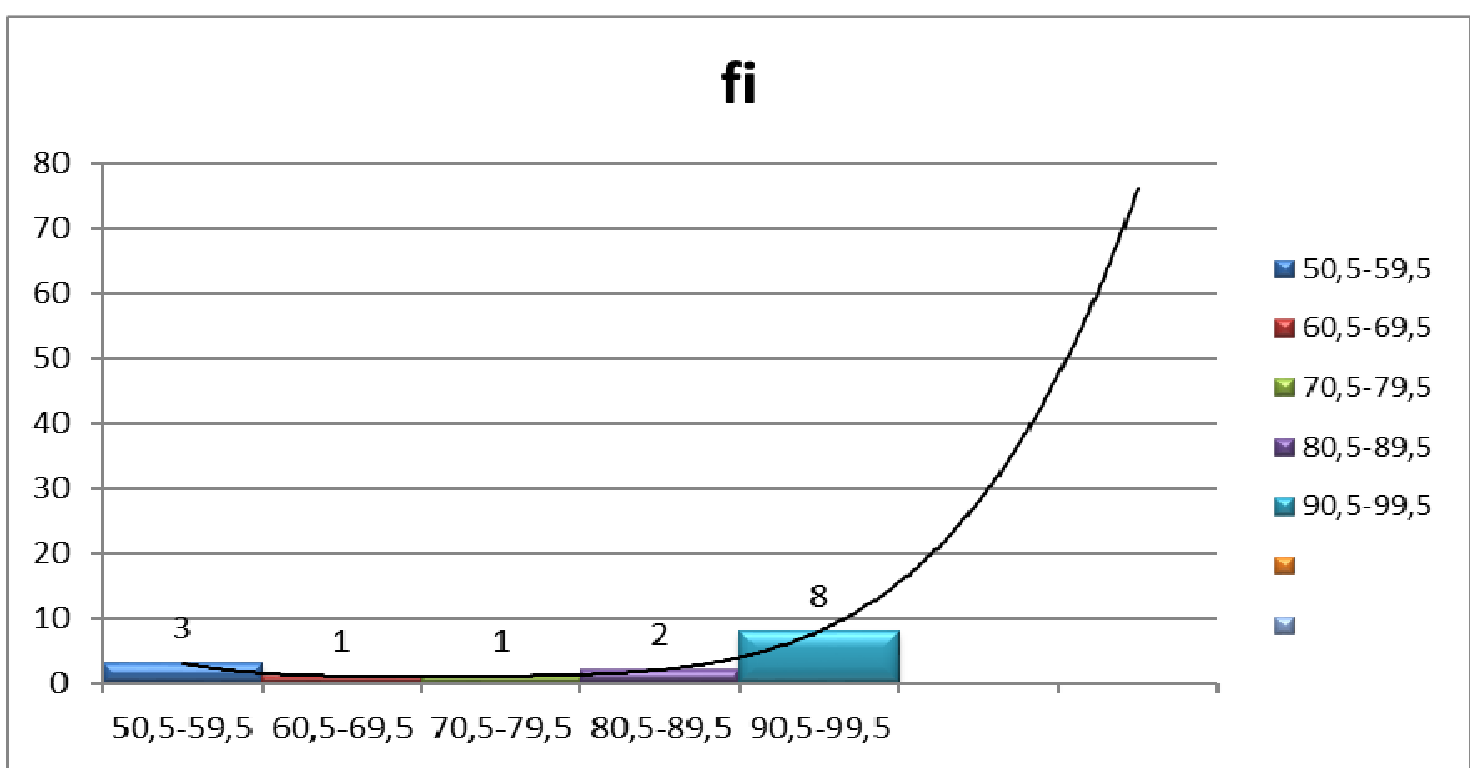

Figure 5. The Histogram and Polygon of the Tenses Mastery Scores of the Students Having High Creativity Level and Taught by Using Gamification

6. The Description of the Tenses Mastery Scores of the Students Having Low Creativity Level and Taught by Using Gamification

The tenses mastery scores of the students having low creativity and taught by using gamification are presented in table 13.

Table 13. The Tenses Mastery Scores of the Students Having Low Creativity Level and Taught by Using Gamification

\begin{tabular}{lllllll}
\hline N & Mean & Mode & Median & Standard Deviation & Highest & Lowest \\
\hline 15 & 72.1 & 80.26 & 68 & 13.49 & 87 & 43 \\
\hline
\end{tabular}

As revealed in the table 13, it is figured out that the mean score of tenses mastery of the students having low creativity and taught by using Gamification is 72.1 , the median is 68 , the mode is 80.26 , and the standard deviation is 13.49 . The frequency distribution, the polygon, and the histogram of the students' writing are presented in table 14 and figure 6 .

Table 14. The Frequency Distribution of the Tenses Mastery Scores of the Students Having Low Creativity and Taught by Using Gamification

\begin{tabular}{lccccc}
\hline $\begin{array}{l}\text { Group } \\
\text { Limit }\end{array}$ & $\begin{array}{l}\text { Median } \\
\left(\mathbf{X}_{\mathbf{i}}\right)\end{array}$ & $\mathbf{f}_{\mathbf{i}}$ & $\mathbf{X}_{\mathbf{i}} \mathbf{f}_{\mathbf{i}}$ & $\mathbf{X}_{\mathbf{i}}{ }^{2}$ & $\mathbf{f}_{\mathbf{i}} \mathbf{X}_{\mathbf{i}}{ }^{\mathbf{2}}$ \\
\hline $43.5-51.5$ & 47.5 & 3 & 142.5 & 20306.3 & 60918.8 \\
\hline $52.5-60.5$ & 56.5 & 0 & 0 & 0 & 0 \\
\hline $61.5-69.5$ & 65.5 & 1 & 65.5 & 4290.25 & 4290.25 \\
\hline $70.5-78.5$ & 74.5 & 5 & 372.5 & 138756 & 693781 \\
\hline $79.5-87.5$ & 83.5 & 6 & 501 & 251001 & 1506006 \\
\hline Total & & & & & 414354 \\
\hline
\end{tabular}




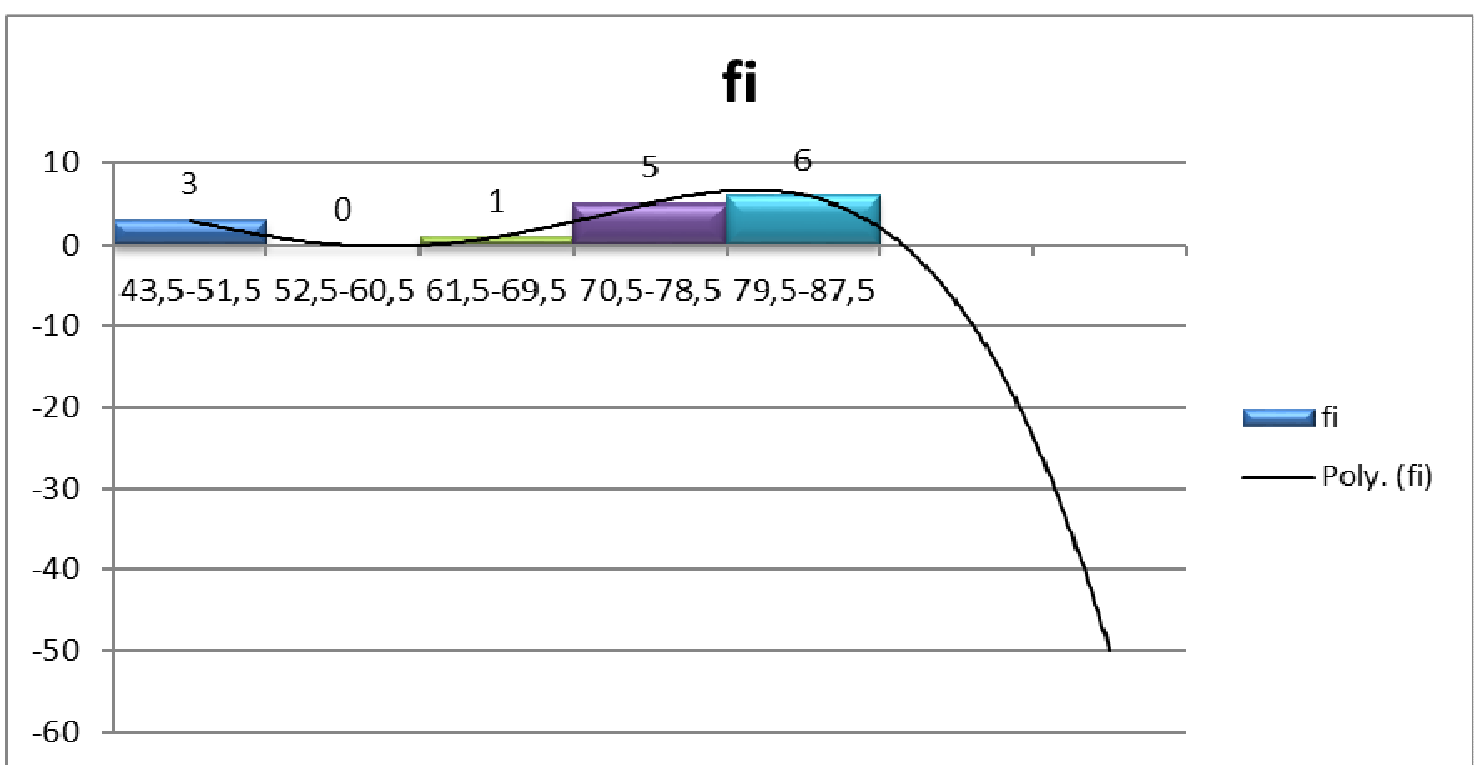

Figure 6. The Histogram and Polygon of the Tenses Mastery Scores of the Students Having Low Creativity Level and Taught by Using Gamification

7. The Description of the Tenses Mastery Scores of the Students Having High Creativity Level and Taught by Using Conventional Teaching Method

The tenses mastery scores of the students having high creativity and taught by using conventional teaching method are presented in table 15.

Table 15. The Tenses Mastery Scores of the Students Having High Creativity Level and Taught by Using Conventional Teaching Method

\begin{tabular}{lllllll}
\hline N & Mean & Mode & Median & $\begin{array}{l}\text { Standard } \\
\text { Deviation }\end{array}$ & Highest & Lowest \\
\hline 15 & 65.9 & 86.60 & 63.50 & 22.68 & 94 & 28 \\
\hline
\end{tabular}

As shown in the table 15, it is seen that the mean score of tenses mastery of the students having high creativity and taught by using conventional teaching method is 65.9 , the median is 63.50 , the mode is 86.60 , and the standard deviation is 22.68 . The frequency distribution, the polygon, and the histogram of the students' tenses mastery are described in table 16 and figure 7.

Table 16. The Frequency Distribution of the Tenses Mastery Scores of the Students Having High Creativity and Taught by Using Conventional Teaching Method

\begin{tabular}{|c|c|c|c|c|c|c|}
\hline $\begin{array}{l}\text { Group } \\
\text { Limit }\end{array}$ & $\begin{array}{l}\text { Median } \\
\left(\mathbf{X}_{\mathbf{i}}\right)\end{array}$ & $\mathbf{f}_{\mathbf{i}}$ & $\mathbf{X}_{\mathbf{i}} \mathbf{f}_{\mathbf{i}}$ & $\mathbf{X}^{2}$ & $\mathbf{f}_{\mathbf{i}} \mathbf{X}_{\mathrm{i}}^{2}$ & \\
\hline $28.5-41.5$ & 35 & 4 & 140 & 19600 & 78400 & \\
\hline $42.5-54.5$ & 48.5 & 1 & 48.5 & 2352.25 & 2352.25 & \\
\hline $55.5-67.5$ & 61.5 & 2 & 123 & 15129 & 30258 & \\
\hline $68.5-80.5$ & 74.5 & 2 & 149 & 22201 & 44402 & \\
\hline $81.5-94.5$ & 88 & 6 & 528 & 278784 & 1672704 & \\
\hline \multicolumn{3}{|c|}{ Total } & 15 & 988.5 & 338066 & 1828116 \\
\hline
\end{tabular}




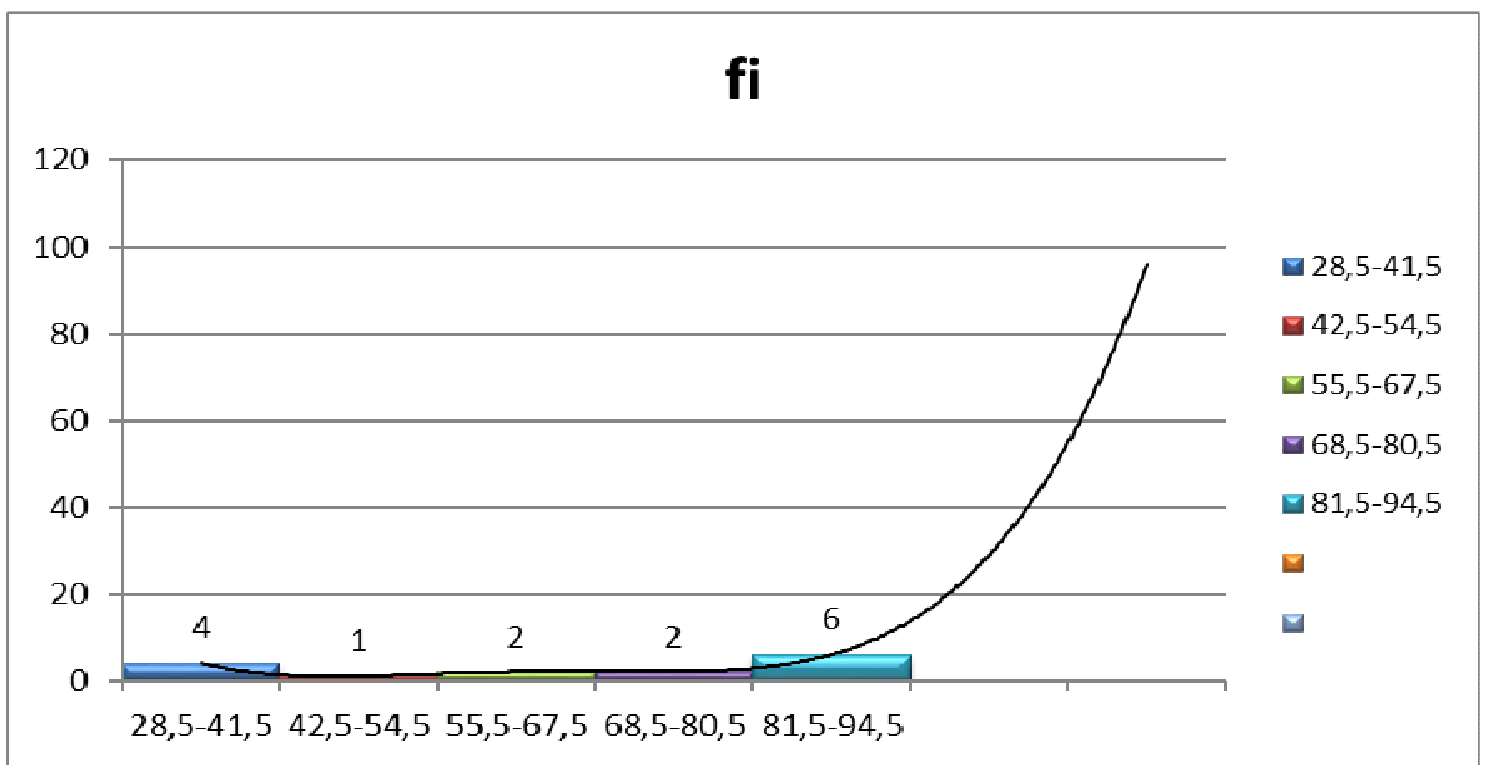

Figure 7. The Histogram and Polygon of the Tenses Mastery Scores of the Students Having High Creativity Level and Taught by Using Conventional Teaching Method

8. The Description of the Tenses Mastery Scores of the Students Having Low Creativity Level and Taught by Using Conventional Teaching Method

The tenses mastery scores of the students having low creativity and taught by using conventional teaching method are presented in table 17.

Table 17. The Tenses Mastery Scores of the Students Having Low Creativity Level and Taught by Using Conventional Teaching Method

\begin{tabular}{lllllll}
\hline N & Mean & Mode & Median & $\begin{array}{l}\text { Standard } \\
\text { Deviation }\end{array}$ & Highest & Lowest \\
\hline 15 & 58.13 & 79.54 & 62 & 23.24 & 80 & 11 \\
\hline
\end{tabular}

Based on the table 17, it is shown that the mean score of tenses mastery of the students having low creativity and taught by using conventional teaching method is 58.13 , the median is 62, the mode is 79.54, and the standard deviation is 23.24. The frequency distribution, the polygon, and the histogram of the students' tenses mastery are described in table 18 and figure 8.

Table 18. The Frequency Distribution of the Tenses Mastery Scores of the Students Having Low Creativity and Taught by Using Conventional Teaching Method

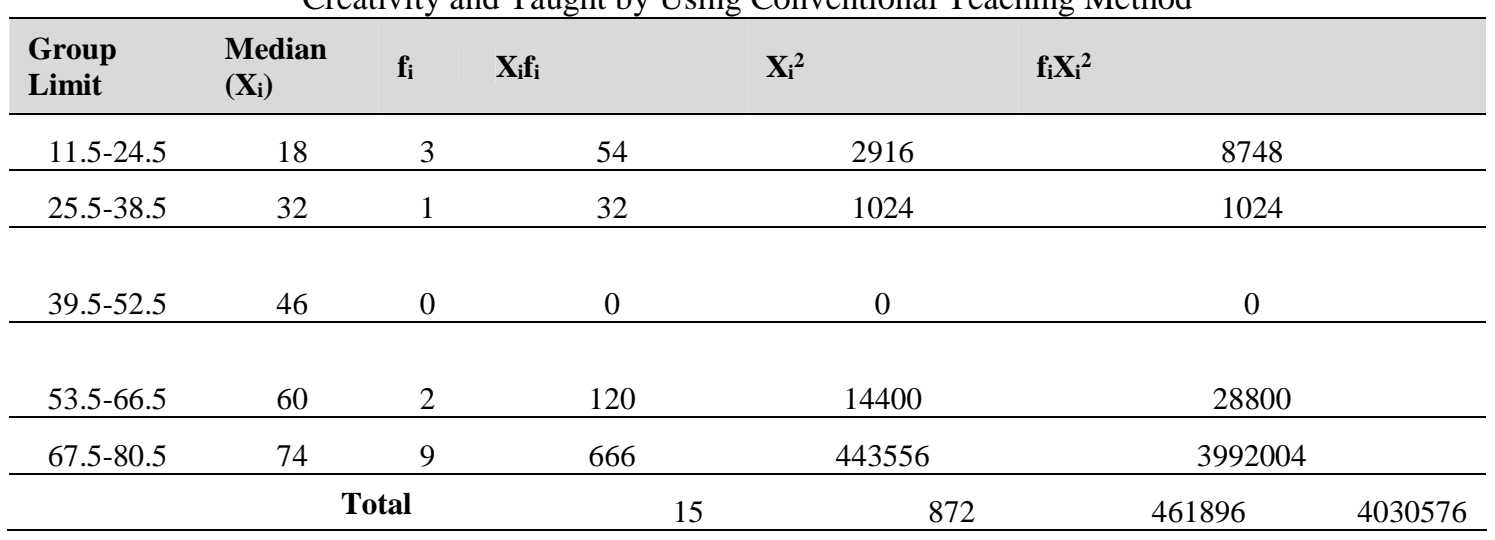




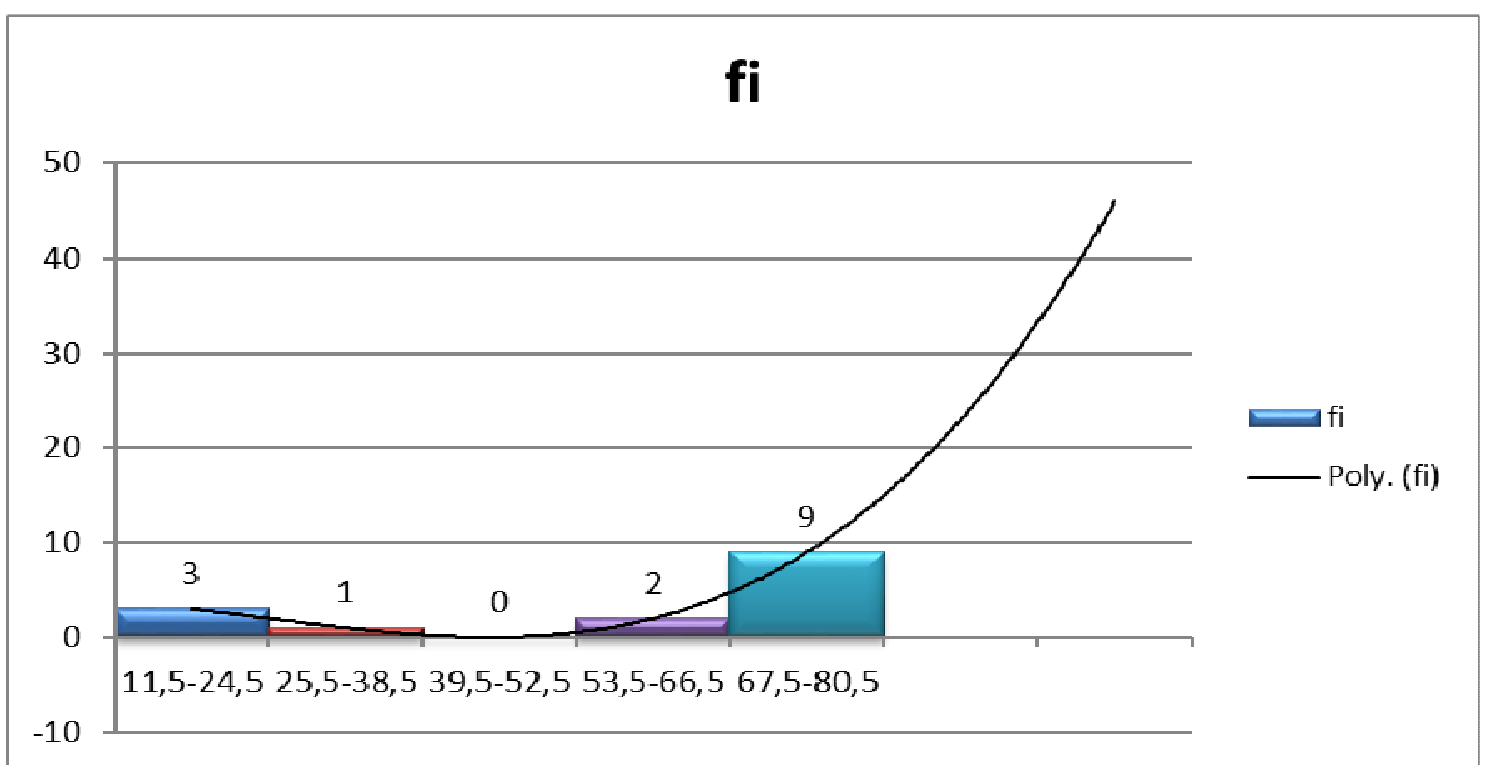

Figure 8. The Histogram and Polygon of the Tenses Mastery Scores of the Students Having Low Creativity Level and Taught by Using Conventional Teaching Method

\section{Data Analysis}

Prior to analyzing the data using inferential analysis, the distribution of the sample must be normal and homogeneous. The followings are about the results and the computations of normality and homogeneity tests applied to the obtained data.

\section{Normality Test}

Lilliefors test was employed to find out the normality of teaching methods and creativity level. The tests results are described in the table 19.

Table 19. The Summary of Normality Test using Lilliefors

\begin{tabular}{|c|c|c|c|c|c|c|}
\hline No & Variables & $\mathrm{L}_{\mathrm{o}}$ & $\begin{array}{l}\text { Number of } \\
\text { Data }\end{array}$ & $\mathrm{L}_{\text {table }}$ & Test decision & Description \\
\hline 1 & $\begin{array}{l}\text { Tenses Mastery Scores } \\
\text { of the Students Taught } \\
\text { by Using Gamification }\end{array}$ & 0.1582 & 30 & 0.161 & $\mathrm{H}_{\mathrm{o}}$ is accepted & Normal \\
\hline 2 & $\begin{array}{l}\text { Tenses Mastery Scores } \\
\text { of the Students Taught } \\
\text { by Using Conventional } \\
\text { Teaching Method }\end{array}$ & 0.1446 & 30 & 0.161 & $\mathrm{H}_{\mathrm{o}}$ is accepted & Normal \\
\hline 3 & $\begin{array}{l}\text { Tenses Mastery Scores } \\
\text { of the Students Having } \\
\text { High Creativity }\end{array}$ & 0.1527 & 30 & 0.161 & $\mathrm{H}_{\mathrm{o}}$ is accepted & Normal \\
\hline 4 & $\begin{array}{l}\text { Tenses Mastery Scores } \\
\text { of the Students Having } \\
\text { Low Creativity }\end{array}$ & 0.1412 & 30 & 0.161 & $\mathrm{H}_{\mathrm{o}}$ is accepted & Normal \\
\hline 5 & $\begin{array}{l}\text { Tenses Mastery Scores } \\
\text { the Students Having } \\
\text { High Creativity and } \\
\text { Taught by Using } \\
\text { Gamification }\end{array}$ & 0.2182 & 15 & 0.220 & $\mathrm{H}_{\mathrm{o}}$ is accepted & Normal \\
\hline 6 & $\begin{array}{l}\text { Tenses Mastery Scores } \\
\text { the Students Having } \\
\text { Low Creativity and } \\
\text { Taught by Using } \\
\text { Gamification }\end{array}$ & 0.2099 & 15 & 0.220 & $\mathrm{H}_{\mathrm{o}}$ is accepted & Normal \\
\hline
\end{tabular}


ISSN: 2723-6978

http://jurnal.unissula.ac.id/index.php/JAMR DOI: http://dx.doi.org/10.30659/JAMR.1.2.73-97

\begin{tabular}{|c|c|c|c|c|c|c|}
\hline 7 & $\begin{array}{l}\text { Tenses Mastery Scores } \\
\text { the Students Having } \\
\text { High Creativity and } \\
\text { Taught by Using } \\
\text { Conventional Teaching } \\
\text { Method }\end{array}$ & 0.2190 & 15 & 0.220 & $\mathrm{H}_{\mathrm{o}}$ is accepted & Normal \\
\hline 8 & $\begin{array}{l}\text { Tenses Mastery Scores } \\
\text { the Students Having } \\
\text { Low Creativity and } \\
\text { Taught by Using } \\
\text { Conventional Teaching } \\
\text { Method }\end{array}$ & 0.2175 & 15 & 0.220 & $\mathrm{H}_{\mathrm{o}}$ is accepted & Normal \\
\hline
\end{tabular}

\section{Homogeneity Test}

The result of the homogeneity test can be seen in table 20 .

Table 20. The Summary of Homogeneity Test

\begin{tabular}{|c|c|c|c|c|c|}
\hline Sampel & $\mathrm{df}$ & $1 /(\mathrm{df})$ & $\mathrm{Si}^{2}$ & $\log \mathrm{si}^{2}$ & (df) $\log \mathrm{si}^{2}$ \\
\hline 1 & 14 & 0.07143 & 4.8867 & 0.6890 & 9.6462 \\
\hline 2 & 14 & 0.07143 & 4.0025 & 0.6023 & 8.4326 \\
\hline 3 & 14 & 0.07143 & 3.921 & 0.5934 & 8.3076 \\
\hline \multirow[t]{2}{*}{4} & 14 & 0.07143 & 3.8765 & 0.5884 & 8.2382 \\
\hline & & 0.28571 & & & 34.6246 \\
\hline
\end{tabular}

$$
\begin{array}{rrr} 
& \mathrm{s}_{1}{ }^{2}= & 4.8867 \\
\mathrm{~s}_{2}{ }^{2}= & 4.0025 \\
\mathrm{~s}^{2}= & 3.921 \\
\mathrm{~s}^{2}= & 3.8765 \\
\mathrm{~s}^{2}= & 4.17168 \\
& & 0.62031 \\
\mathrm{~B}= & \left(\log \mathrm{s}^{2}=\right. & \\
= & 35.9780071 & \\
& & \\
& & \\
x^{2}=(\ln 10)\left\{\mathrm{B}-\sum\left(\mathrm{n}_{\mathrm{i}}-1\right) \log \mathrm{s}_{\mathrm{i}}{ }^{2}\right\} & \\
& =\mathbf{3 . 1 1}
\end{array}
$$

Based on the result of homogeneity test, it can be seen that the score of $\chi_{0}^{2}=3.11$. According to the table of Chi-Square distribution with the significance level $\alpha=0.05$, the value of $\left.\chi_{t}^{2} 0.05\right)$ is 3.16. Due to $\chi_{0}^{2}(3.11)$ is lower than $\chi_{t}^{2} 0.05(3.16)$ or $\chi_{0}^{2}<\chi_{t}^{2}(3.11<3.16)$, it can be concluded that the date are homogeneous. 


\section{Testing Hypotheses}

The summary of ANOVA 2 X 2 can be seen in table 21 and table 22.

Table 21. The Summary of the Mean Scores

\begin{tabular}{llll}
\hline \multirow{2}{*}{ CREATIVITY (B) } & \multicolumn{2}{l}{ TEACHING METHODS $(\mathrm{A})$} & Total \\
\cline { 2 - 3 } & GAMIFICATION $\left(\mathrm{A}_{1}\right)$ & $\mathrm{CTM}\left(\mathrm{A}_{2}\right)$ & $\bar{X}=66.16$ \\
\hline High Creativity $\left(\mathrm{B}_{1}\right)$ & $\bar{X} \mathrm{~A}_{1} \mathrm{~B}_{1}=75.9$ & $\bar{X} \mathrm{~A}_{2} \mathrm{~B}_{1}=56.4$ & $\bar{X}=55,03$ \\
Low Creativity $\left(\mathrm{B}_{2}\right)$ & $\bar{X} \mathrm{~A}_{1} \mathrm{~B}_{2}=61.1$ & $\bar{X} \mathrm{~A}_{2} \mathrm{~B}_{2}=48.9$ & $\bar{X}=60.6$ \\
Total & $\bar{X}=68.53$ & $\bar{X}=52.66$ & $\bar{X}$ \\
\hline
\end{tabular}

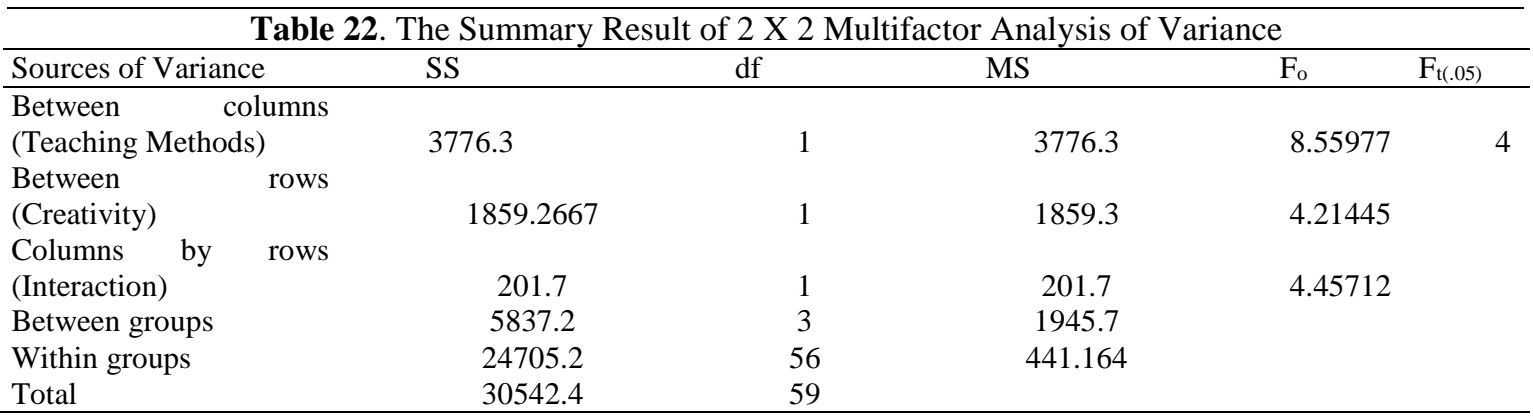

From the computation result of ANOVA test, it can be concluded that:

1. $F_{o}$ between columns, the comparative analysis between the effect of teaching methods using Gamification and Conventional Teaching Method, shows that $F_{o}$ is 8.55. The Ft at the level of significance $\alpha=0.05\left(\mathrm{~F}_{\mathrm{t}(.05)}\right)$ is $4 . \mathrm{F}_{\mathrm{o}}(8.55)$ is higher than $\mathrm{F}_{\mathrm{t}(.05)}(4)$. It means Ho is rejected and there is a significant difference between Gamification and Conventional Teaching Method to enhance tenses mastery. It can be concluded that the teaching methods for improving tenses mastery differ significantly from one another in their effect on the performance of the subjects in the experiment. The mean score of the students taught using Gamification (68.53) is higher than that of those taught using CTM (52.66). It is summarized that Gamification is more effective than CTM to enhance tenses mastery.

2. The score of $F_{o}$ between rows (creativity) is 4.21 while the score of $F_{t}$ at the level of significance $\alpha=0.05\left(\mathrm{~F}_{\mathrm{t}(.05)}\right)$ is $4 . \mathrm{F}_{\mathrm{o}}(4.21)$ is higher than $\mathrm{Ft}$ (4). It means that $\mathrm{H}_{\mathrm{o}}$ is rejected and the difference between tenses mastery score of the students who have high creativity and those who have low creativity is significant. Based on the calculation of the mean scores, the mean score of the students who have high creativity (66.16) is higher than that of those who have low creativity (55.03). Then, it is summarized that the students who have high creativity have better tenses mastery than those who have low creativity.

3. The score of $F_{o}$ columns by rows (interaction) is 4.45 and the score of $F_{t}$ at the level of significance $\alpha=0.05$ is 4 . Because $F_{o}>F_{t(.05)}$ or $F_{o}(4.45)$ is higher than $F_{t}(4)$, there is an interaction effect between two variables, teaching methods and students' creativity on the students' tenses mastery. In other words, it can be said that the effects of teaching methods on students' tenses mastery depend on the students' degree of creativity.

The result of analysis of the data using Tukey's HSD test is described in table 23.

Table 23. The Result of Tukey's HSD Test

\begin{tabular}{lllllll}
\hline No & Data & Sample & $\mathrm{q}_{\mathrm{o}}$ & $\mathrm{q}_{\mathrm{t}}$ & $\alpha$ & Status \\
\hline 1. & $\mathrm{A}_{1}$ and $\mathrm{A}_{2}$ & 30 & 6.21 & 3.81 & 0.05 & Significant \\
2. & $\mathrm{B}_{1}$ and $\mathrm{B}_{2}$ & 30 & 7.45 & 3.81 & 0.05 & Significant \\
3. & $\mathrm{A}_{1} \mathrm{~B}_{1}$ and $\mathrm{A}_{2} \mathrm{~B}_{1}$ & 15 & 10.63 & 3.87 & 0.05 & Significant \\
4. & $\mathrm{A}_{1} \mathrm{~B}_{2}$ and $\mathrm{A}_{2} \mathrm{~B}_{2}$ & 15 & 0.31 & 3.87 & 0.05 & Not Significant \\
\hline
\end{tabular}

From the table 23, it can be seen that: 
1. The score of $\mathrm{q}_{\mathrm{o}}$ between columns is 6.21 and the score of $\mathrm{q}_{\mathrm{t}}$ of Tukey's table at the level of significance $\alpha=0.05$ is 3.81. Because $\mathrm{q}_{\mathrm{o}}>\mathrm{q}_{\mathrm{t}}$ or $\mathrm{q}_{\mathrm{o}}$ (6.21) is higher than $\mathrm{q}_{\mathrm{t}}(.05)$ (3.81), using Gamification differs significantly from Conventional Teaching Method to enhance tenses mastery.

2. The score of $\mathrm{q}_{\mathrm{o}}$ between rows is 7.45 and the score of $\mathrm{q}_{\mathrm{t}}$ of Tukey's table at the level of significance $\alpha=0.05$ is 3.81. Because $\mathrm{q}_{\mathrm{o}}>\mathrm{q}_{\mathrm{t}}$ or $\mathrm{q}_{\mathrm{o}}$ (7.45) is higher than $\mathrm{q}_{\mathrm{t}}(.05)(3.81)$, it can be concluded that there is a significant difference on the students' tenses mastery score between those who have high creativity and those who have low creativity.

3. The score of $\mathrm{q}_{\mathrm{o}}$ between cells A1B1 and A2B1 is 10.63 and the score of $\mathrm{q}_{\mathrm{t}}$ of Tukey's table at the level of significance $\alpha=0.05$ is 3.87 . Because $\mathrm{q}_{\mathrm{o}}>\mathrm{q}_{\mathrm{t}}$ or $\mathrm{q}_{\mathrm{o}}(10.63)$ is higher than $\mathrm{q}_{\mathrm{t}}(.05)$ (3.87), it can be concluded that using Gamification differs significantly from Conventional Teaching Method to improve tenses mastery for the students who have high creativity.

4. The score of $\mathrm{q}_{\mathrm{o}}$ between cells $\mathrm{A} 1 \mathrm{~B} 2$ and $\mathrm{A} 2 \mathrm{~B} 2$ is 0.31 and the score of $\mathrm{q}_{\mathrm{t}}$ of Tukey's table at the level of significance $\alpha=0.05$ is 3.87. Because $\mathrm{q}_{\mathrm{o}}<\mathrm{q}_{\mathrm{t}}$ or $\mathrm{q}_{\mathrm{o}}(0.31)$ is lower than $\mathrm{q}_{\mathrm{t}}(.05)$ (3.87), it can be concluded that using Gamification does not differ significantly from Conventional Teaching Method to enhance tenses mastery for the students who have low creativity.

\section{Discussion}

1. Gamification is more effective than Conventional Teaching Method in enhancing tenses mastery

Teaching tenses in English requires the teachers' hard efforts to attract the students' interest and motivation as the tenses or what so called a little piece of grammar in English is considered difficult to master by the students. Not only do the teachers have to prepare an interesting and interactive material, but they are also supposed to provide a memorable learning atmosphere for the students. Here comes gamification as one of the alternatives to boost up the students' learning interest in tenses.

Gamification plays a pivotal role in the teaching and learning of tenses especially simple present tense, simple past tense, and simple future tense which are taught to the second semester students of nursing diploma III of faculty of health at Universitas Harapan Bangsa. By utilizing one of gamification types, quizizz, the teachers are able to enhance the students' tenses mastery due to the fact that this online application has several features and uses such as we can add pictures, input equation, use some possible answers, and set up the time. Quizizz also enables the teacher to present the materials as well as the review quiz for each meeting so that the students can figure out whether they have already mastered the certain tenses or not and it can be done in an interesting and fun game.

In improving the students' mastery on how to distinguish among the learned tenses, gamification (quizizz) has a randomized answer feature by which the students can notice the correct or incorrect answers for each question and why the errors have occurred. Besides, gamification can assist the students to understand the meaning and form of each learned tenses by providing the materials designed by the teachers beforehand. Moreover, students could learn the tenses in their own level and get the feedback immediately about their learning progress.

In addition to having invaluable features, quizizz also possesses some other interesting characteristics such as leader board, rewards, and player icons. Moreover, not only can it be accessed using laptop, the students can also use their mobile phones to get connected to quizizz so that the students can play the game anytime and anywhere. Gamification can also provide learning model characteristics such as challenges, satisfaction, rewards, dependence. Several studies concur with the findings of this study which show positive attitude toward the use of gamification in learning and which reveal that by using gamification, the students' engagement, 
experience and achievement in the learning improved (Lee \& Hammer, 2016; Partovi \& Razavi, 2019; Chou, 2017; Romdhoni \& Wibowo, 2014; Bozkurt \& Durak, 2018; and Leaning, 2015.

On the other hand, teaching tenses in English using conventional teaching method do not improve the students' mastery on tenses as the teachers only present the materials in a lecturing style by which the students listen to, watch, and do exercises given by their teachers. This lecturing method cannot help the students to gain a better knowledge on simple present tense, simple past tense and simple future tense. The students tend to be passive while the teachers like to dominate the teaching and learning process. The students are not motivated to find out more deeply on the form, use and meaning of each learned tenses. During the meeting, the teacher first introduces the form, then followed by the meaning and the use of the tenses and it is conducted in every meeting. The students' opportunity to ask and correct their wrongs is very limited since the teacher frequently guide the students to notice the errors they have made with a very limited feedback and review.

Moreover, by utilizing the conventional teaching method to enhance the students' mastery, the teacher rarely uses various teaching and learning methods so that the students are not able to develop themselves and lack of chances to have interaction among students because it only applies a teacher-centred learning. Conventional teaching method cannot also provide something challenging and fun for the students. Besides, the existence of other supporting media is rarely used by the teacher in both online and offline classrooms. That really reveals the inadequacy of utilizing technology-based learning media thus it cannot attract the students' attention. This finding is in line with the other previous studies which report that the conventional teaching method does not give merits to the learning (Liu \& Long, 2014; Noor, 2019; and Isnaini, 2014.

2. The students who have high creativity have better tenses mastery than those who have low creativity

Creativity is defined as the act of turning new and original ideas into reality. It is closely related to the flexibility to understand the universe in new ways, to seek out hidden patterns, to form connections between ostensibly unrelated phenomena, and to get solutions. In the teaching and learning process, not only do the teachers who have to be creative in delivering the materials, but the students are also required to use their creative mind and to think out of the box pertaining the materials they are learning.

The students who have high creativity have a better understanding on what they see, read, and listen. The students can figure out their own way to master what they have and are learning without having any constraint in their mind. The students with high creativity level have a better tenses mastery than those with low level of creativity since the creative students like to form their mind to recognize and use each learned tenses, while those with low creativity have no idea of what to do with the materials they have and are learning. This finding concurs with other research findings which show that creative students possess ability to think beyond what the other students cannot do (Wolf, 2014; and Precourt, 2013).

On the other hand, students with low level of creativity cannot express their feelings and mind, even they tend to be passive. They lack of ideas and often surrender once they need to do something. According to the students who have low creative thinking are sometimes conventional, timid, lack of confidence, and conforming. They often do not learn seriously. Low level creativity students do not seem to be capable of finishing hard effort to check additional thanks to the very fact that it is challenging for them to return up with their own recent and original concepts throughout the educational method within the classroom.

Based on the explanation above, it can be concluded that the students with high creativity have better tenses mastery than the students with low creativity.

3. There is an interaction effect between teaching methods and creativity on the students' tenses mastery. 
Gamification can assist the students to acquire a better knowledge and mastery on tenses in English. It can also develop all of the indicators of grammar like form, use and meaning. Gamification requires the students to competitively work against the other students in order to gain a higher point and to be a leader or a winner of the game. Gamification also allows the students to come up their mind about what they have known, what they have not known and what they want to know about the tenses and it is carried out before the teacher presents the materials and before giving the games.

By occupying quizizz (one of gamification kinds), the students can get immediate feedback and correction if their answers do not meet the teacher's expectation. Moreover, the teacher can also conduct the game based on the students' level starting from the easiest questions to the hardest questions. Even gamification could give significant contribution to enhancing the language learning especially by practicing more and more in a fun and interactive way. A research conducted by Jusuf in 2016 is in line with the findings of this study which clearly state that by using gamification, it could be an alternative to create a more interesting, fun, effective and creative learning process.

It is inevitable that there are two kinds of creative students; high creative and low creative students. The students with high creativity will easily develop and construct their minds. They can master the forms, uses, and meanings of each learned tenses. Meanwhile, the students with low level of creativity do not get influenced by the teaching methods applied in the teaching of tenses. Both gamification and conventional teaching method do not differ significantly to enhance tenses mastery. The students with low level of creativity are frequently shy and unwilling to try a new thing. The students who have low creativity are usually conventional, timid, lack of confidence, and conforming. They often do not learn seriously. Low level creativity students are not capable of completing hard effort to study more due to the fact that it is not easy for them to come up with their own fresh and original ideas during the learning process in the classroom. Therefore, it can be concluded that there is no significant difference between gamification and conventional teaching method to improve tenses mastery for the students with low creativity. It means that gamification and conventional teaching method are equal to teach the students who have low creativity

\section{CONCLUSION}

Based on the result of the hypotheses testing, the research findings are (1) gamification is more effective than conventional teaching method to improve tenses mastery; (2) The students with high creativity have better tenses mastery than students with low creativity; and (3) There is an interaction effect between the teaching methods and the students' creativity on the students' tenses mastery. This can be seen from the finding of this research that for high creative students, gamification is more effective than conventional teaching method. Meanwhile, for low creative students, gamification is as effective as conventional teaching method.

\section{ACKNOWLEDGEMENT}

The researchers vastly feel gratitude to Universitas Harapan Bangsa for granting us the funding and opportunity to conduct this research. Besides, we would like to thank all of the students who have participated in this study.

\section{REFERENCES}

Al-hadithy, T., \& Ali, S. (2018). Gamification in Learning English for Academic Purposes: Designing Assessment for Learning Using. (5), 66-70.

Alsawaier, R. S. (2018). The effect of gamification on motivation and engagement. International Journal of Information and Learning Technology, 35(1), 56-79. 
https://doi.org/10.1108/IJILT-02-2017-0009

Attali, Y. \& Arieli. (2015). Gamification in assessment: Do points affect test performance?. Computers and Education, 83, 57-63.

Bongers, H. (1946). Basic English. English Studies, 27(1-6), 161-174. https://doi.org/10.1080/00138384608596774

Bozkurt, A., \& Durak, G. (2018). A systematic review of gamification research: In pursuit of homo ludens. International Journal of Game-Based Learning, 8(3), 15-33. https://doi.org/10.4018/IJGBL.2018070102

Chou, Y. (2017). Actionable Gamification Beyond Points, Badges, and Leaderboards. Journal of Chemical Information and Modeling, 8(9), 1-58. https://doi.org/10.1017/CBO9781107415324.004

Dale, S. (2014). Gamification: Making work fun, or making fun of work? Business Information Review, 31 (2), 82-90.

Davis, M.H., \& McPartland, J. M. (2012). High School Reform and Student Engagement. In S. L. Christenson, A. L. Rashly, \& C. Wylie (Eds), Handbook of Research on Student.

Dehghanzadeh, H., Fardanesh, H., Hatami, J., Talaee, E., \& Noroozi, O. (2019). Using gamification to support learning English as a second language: a systematic review. Computer Assisted Language Learning, O(0), 1-24. https://doi.org/10.1080/09588221.2019.1648298

Dichev, C., \& Dicheva, D. (2017). Gamifying education: what is known, what is believed and what remains uncertain: a critical review. In International Journal of Educational Technology in Higher Education (Vol. 14). https://doi.org/10.1186/s41239-017-0042-5

Figueroa Flores, J. F. (2015). Using Gamification to enhance second language learning. Digital Education Review, (27), 32-54. https://doi.org/10.1344/der.2015.27.32-54

García, L. A., \& Alvaro, B. T. (2017). Gamification in English Teaching in Primary Education Resumen. Thesis.

Gonzales, C. S., Gomez, N., Navarro, V., Cairos, M., Quirce, C., Toledo, P., \& MarreroGordillo, N. (2016). Learning healthy lifestyle through active videogames, motor games and the gamification of educational activities. Computers in Human Behavior, 55, 529551.

Hanifah, R., \& Adopsi, P. (2017). Penggunaan Gamifikasi dalam Proses Pembelajaran Heni Jusuf Perangkingan Usability Website menggunakan Metode Multiple Criteria Decision Analisys Sekretariat Redaksi : Program Pascasarjana Universitas Budi Luhur Jl . Raya Ciledug , Petukangan Utara, Jakar. (September 2016).

Isnaini, E. (2014). The Effectiveness of Inquiry Based Teaching to Teach Grammar. Eltin Journal, 2(II), 1-6.

Jaeger, G. (2019). The Effectiveness of Teaching Traditional Grammar on Writing Composition at the High School Level. Journal of Chemical Information and Modeling, 53(9), 16891699.

Kapp, K. (2013). The gamification of learning and instruction fieldbook: Ideas into practice. NY: Wiley

Landers, R. N. (2014). Developing a Theory of Gamified Learning: Linking Serious Games and 
Gamification of Learning. Simulation and Gaming, 45(6), 752-768. https://doi.org/10.1177/1046878114563660

Leaning, M. (2015). A study of the use of games and gamification to enhance student engagement, experience and achievement on a theory-based course of an undergraduate media degree. Journal of Media Practice, 16(2), 155-170. https://doi.org/10.1080/14682753.2015.1041807

Lee \& Hammer. (2016). Penggunaan Gamifikasi dalam Proses Pembelajaran. Jurnal TICOM, $5(1), 1-6$.

Liu, C., \& Long, F. (2014). The Discussion of Traditional Teaching and Multimedia Teaching Approach in College English Teaching. (Icmess). https://doi.org/10.2991/icmess14.2014.9

Lui, S. (2013). Use of Gamification in Vocabulary Learning: A Case Study in Macau. CELC Symposium, 90-97. Retrieved from http://www.nus.edu.sg/celc/research/books/4th Symposium proceedings/13). Sze Lui.pdf

Matallaoui, A., Koivisto, J., Hamari, J., \& Zarnekow, R. (2017). How Effective Is ĐExergamificationÓ? A Systematic Review on the Effectiveness of Gamification Features in Exergames. Proceedings of the 50th Hawaii International Conference on System Sciences (2017), 3316-3325. https://doi.org/10.24251/hicss.2017.402

Partovi, T., \& Razavi, M. R. (2019). The effect of game-based learning on academic achievement motivation of elementary school students. Learning and Motivation, 68(June), 101592. https://doi.org/10.1016/j.lmot.2019.101592

Pradana, F., Bachtiar, F. A., \& Priyambadha, B. (2018). Pengaruh Elemen Gamification Terhadap Hasil Belajar Siswa Pada E-Learning Pemrograman Java. Semnasteknomedia, (February), 7-12.

Prambayun, A., Suyanto, M., \& Sunyoto, A. (2016). Model gamifikasi untuk sistem manajemen pembelajaran. 6-7.

Precourt, G. (2013). What we know about creativity. Journal of Advertising Research, 53(3), 238-239. https://doi.org/10.2501/JAR-53-3-238-239

R.M, M. (1994). Kreativitas. Mudra (JURNAL SENI BUDAYA), 2, 1-1.

Romdhoni, F. H., \& Wibowo, R. P. (2014). Penerapan Gamification Pada Aplikasi Interaktif Pembelajaran SQL Berbasis Web. Jurnal Teknik Pomits, 1(1), 1-6.

Sari, B. W., \& Hartanto, A. D. (2016). Penerapan Konsep Gamification Dalam Merancang Aplikasi Pembelajaran Tenses Bahasa Inggris Berbasis Website Menggunakan Framework Codeigniter Dengan Pola MVC. 17(4), 32-37.

Sari, B. W., Utami, E., Al, H., Sari, B. W., Utami, E., \& Fatta, H. Al. (2015). Pembelajaran Tenses Bahasa Inggris Berbasis Web. Jurnal Ilmiah SISFOTENIKA, 5(2), 155-166.

Setyowati, L. (2017). Pengajaran Literasi Informasi Dengan Konsep Gamification Di Perpustakaan Perguruan Tinggi. UNILIB: Jurnal Perpustakaan, 8(1), 39-50. https://doi.org/10.20885/unilib.vol8.iss1.art4

Sigala, M. (2015). Applying Gamification and Assessing its Effectiveness in a Tourism Context: Behavioural and Psychological Outcomes of the TripAdvisor's Gamification Users. Asia Pacific Journal of Information Systems, 25(1), 179-210. 
Journal of Advanced Multidisciplinary Research

Vol. 1, No. 2, 2020, pp. 73-97

ISSN: 2723-6978

http://jurnal.unissula.ac.id/index.php/JAMR

DOI: http://dx.doi.org/10.30659/JAMR.1.2.73-97

https://doi.org/10.14329/apjis.2015.25.1.179

Wolf, R. (2014). Defining the Concept of Ccreativity. University of Twente, Netherlands, 1-60.

Xiang, O. C., Ann, T. T., Hui, C. Y., \& Yew, L. T. (2014). Effectiveness of gamification in vocational technical education. Proceedings of the European Conference on Games-Based Learning, 2, 636-644.

Yanes, N., \& Bououd, I. (2019). Using gamification and serious games for english language learning. 2019 International Conference on Computer and Information Sciences, ICCIS 2019, (October). https://doi.org/10.1109/ICCISci.2019.8716451 